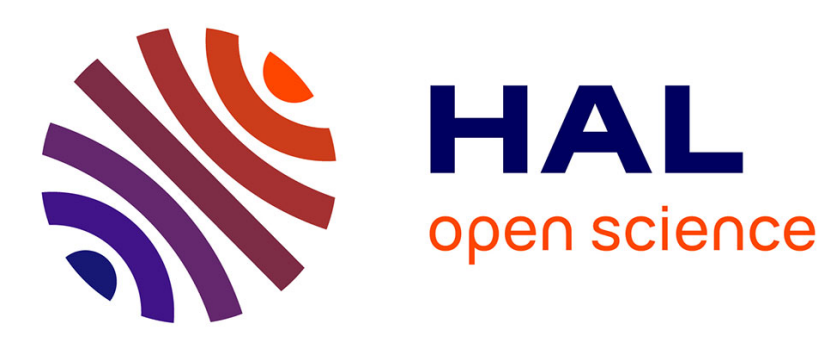

\title{
HfO2-based electrolyte potentiometric oxygen sensors for liquid sodium
}

\author{
J.-L. Courouau, J. Fouletier, M.C. C Steil
}

\section{To cite this version:}

J.-L. Courouau, J. Fouletier, M.C. C Steil. HfO2-based electrolyte potentiometric oxygen sensors for liquid sodium. Electrochimica Acta, 2020, 331, pp.135269. 10.1016/j.electacta.2019.135269 . hal02870278

\section{HAL Id: hal-02870278 \\ https://hal.science/hal-02870278}

Submitted on 16 Jun 2020

HAL is a multi-disciplinary open access archive for the deposit and dissemination of scientific research documents, whether they are published or not. The documents may come from teaching and research institutions in France or abroad, or from public or private research centers.
L'archive ouverte pluridisciplinaire HAL, est destinée au dépôt et à la diffusion de documents scientifiques de niveau recherche, publiés ou non, émanant des établissements d'enseignement et de recherche français ou étrangers, des laboratoires publics ou privés. 


\section{Post print}

Courouau, J. -L., J. Fouletier, et M. C. Steil. « HfO2-Based Electrolyte Potentiometric Oxygen Sensors for Liquid Sodium ». Electrochimica Acta 331 (20 janvier 2020): 135269. https://doi.org/10.1016/j.electacta.2019.135269. 


\title{
$\mathrm{HfO}_{2}$-Based Electrolyte Potentiometric Oxygen Sensors for Liquid Sodium
}

\author{
J.-L. Courouau ${ }^{\mathrm{a} 1}$, J. Fouletier ${ }^{\mathrm{b}}$, M. C. Steil ${ }^{\mathrm{b}}$ \\ ${ }^{a}$ Den-Service de la Corrosion et du Comportement des Matériaux dans leur Environnement (SCCME), CEA, \\ Université Paris-Saclay, F-91191 Gif-sur-Yvette cedex (France) \\ ${ }^{\mathrm{b}}$ Univ. Grenoble Alpes, Univ. Savoie Mont Blanc, CNRS, Grenoble INP, LEPMI, 38000 Grenoble, France
}

Keywords: oxygen sensor, sodium, $\mathrm{HfO}_{2}$, error analysis

\begin{abstract}
The use of potentiometric sensors for the on-line monitoring of oxygen in molten sodium in fast breeder reactors has been studied since the 1970s. However, their lifetime and the reproducibility of the results are inadequate for commercial development. In this study, the performance of the sensor using yttria-doped hafnia is studied and compared with results obtained with thoria- and zirconia-based electrolytes. The yttria-doped hafnia sensor tested, in the form of a tube, exhibits a very reproducible signal and remarkable stability under very low oxygen levels (ca. $0.02 \mathrm{ppm}$ ) and low temperatures $\left(200-300{ }^{\circ} \mathrm{C}\right)$, with a lifetime of ca. two months. Consequently, this electrolyte can be viewed as a promising material for sensing oxygen in molten sodium. The main sources of errors observed in the application of these sensors are reviewed under severe conditions at low temperatures. Discrepancies between the calculated electromotive force (emf) of the cell and the slope of the theoretical Nernst law and the experimental values are analyzed and hypotheses are discussed in order to explain the deviations from the expected values. For the zirconia-based sensor, an original interpretation of
\end{abstract}

\footnotetext{
${ }^{1}$ Corresponding author at: CEA DEN / SCCME, Laboratoire d'étude de la corrosion non aqueuse, 91191 Gif-surYvette cedex (France), e-mail: jean-louis.courouau@cea.fr (J.-L. Courouau)
} 
the sensor's response to a change in oxygen concentration, obtained at low temperatures, is proposed, involving peroxide ions.

\section{Introduction}

The first potentiometric oxygen sensors have been proposed and studied since the end of the 1960s for the determination of oxygen in gases, in liquid metals or for thermodynamic measurements [1-3]. Although Horsley [4] suggested in 1959 the possibility of using this type of sensor for the determination of oxygen in liquid sodium for the objective of corrosion control in the primary and secondary circuits of fast reactors, it was not until the early 1970s that laboratories and research centers began to study this possibility. The main advantages of these sensors would be as follows: (i) their selectivity for oxygen, contrary to plugging indicators; (ii) their sensitivity (less than $0.1 \mathrm{ppm}$ of oxygen); (iii) a real-time control with a response time of a few ten seconds (contrary to the sampling of sodium, followed by chemical analysis, vacuum distillation or neutron activation); and (iv) a large measurement range, i.e., from a few ppm to sodium saturation by oxygen. Even if it is now admitted that the appropriate method for on-line measurement of the oxygen concentration in sodium is the potentiometric sensor based on an oxide electrolyte, the main difficulties for the development of such probes are as follows:

- The stability of oxide electrolytes in the presence of sodium (their corrosion by molten sodium and the additional electronic conductivity of n-type materials), knowing that the lifetime required is in the order of $50,000 \mathrm{~h} \mathrm{[5];}$

- The low resistance of ceramics to thermal and mechanical shocks;

- The effects of radiation;

- The corrosion of metals and alloys [6];

- The electrochemical reaction kinetics at low temperatures, i.e., $250-500^{\circ} \mathrm{C}$. 
It should also be noted that owing to temperature variations in the sodium coolant circuit and to the logarithmic Nernst law, the measurement accuracy for the oxygen concentration is in the order of $10-15 \%$.

A recent exhaustive publication has detailed the evolution of the oxygen probes that are compatible with sodium [7]. In this paper, the main sensors that employ zirconia- or thoriabased electrolytes for the analysis of oxygen concentration in liquid sodium have been reviewed. The criteria for the selection of the oxide electrolytes are based on their chemical compatibility with liquid sodium, their electrical conductivity and their thermomechanical properties.

The state-of-the-art yttria-doped thoria (YDT) electrolyte fulfills the chemical stability requirements in a sodium environment [8-18]. However, the solid electrolyte exhibits many drawbacks: it is a nuclear material, this oxide is difficult to supply, it is very expensive [19], the conventional sintering method requires temperatures of higher than $2000^{\circ} \mathrm{C}$ and the material's mechanical resistance is poor. Various efforts have been devoted to the replacement of long thoria closed-ended tubes by thimbles or disks assembled at the end of a metallic tube through metal brazing or glass soldering. In these conditions, all of the electrolyte material is immersed in the liquid sodium, which avoids temperature gradients [7]. New approaches for the synthesis of nano-sized powders of yttria-doped thoria to allow for lower sintering temperatures have been proposed [19-22].

In parallel with these technical improvements, research has been carried out to replace the thoria-based electrolyte with a more suitable material. Considerable research has been devoted to the development of oxide ion conductors that exhibit high conductivity for applications such as intermediate temperature fuel cells, oxygen sensors, electrolyzers or oxygen permeating membranes [23-27]. In this context, ceria-based electrolytes, lanthanum gallates, etc., have been proposed. These electrolytes exhibit higher conductivity but poor 
stability under reducing atmospheres and/or high sensitivity to decomposition. For many applications, and specifically for oxygen potentiometric sensors, total conductivity is not the key parameter. For the development of oxygen sensors working at very high temperatures, such as oxygen probes in molten steel, thermomechanical stability is the main parameter. In sensors used in the glass industry [28], the high temperature is associated with a corrosive attack of the medium $[29,30]$ and destabilization of the cubic or tetragonal structures with the formation of monoclinic zirconia [31]. In the devices used for the monitoring of oxygen levels in liquid sodium, it is necessary to control the corrosion processes ascribed to the highly reducing conditions, and to the high-radiation environment in the primary coolant circuit. Moreover, to limit the corrosion processes, it is necessary that the sensor works at low temperatures, i.e., in the range of $250-450^{\circ} \mathrm{C}$. In this temperature range, the kinetics of the electrode reactions also become very low. Although zirconia is thermodynamically incompatible in liquid sodium, continued efforts are being made by various groups to employ it as a sensor in sodium at low temperatures. The objective is to use very pure and dense solid electrolyte to reduce the corrosion process for evaluating the lifetime of these sensors $[32,33]$. Their lifetime will be inferior to that of YDT sensors, but a compromise between cost and lifetime could be found. Other oxide ion conductors, such as gadolinia-doped ceria (GDC) or yttria-doped ceria (YDC), have also been explored as oxygen sensors in sodium. However, these sensors failed within 5 $\mathrm{h}$ of utilization $[34,35]$. Simultaneously, the search for new classes of electrolytes is currently in progress. Although $\mathrm{HfO}_{2}$ is significantly more expensive than $\mathrm{ZrO}_{2}$, this oxide could be an attractive material for this application. It should be noted that in previous works, the proposed applications concerned the control of oxygen in metals with high melting points and alloys in non-ferrous metallurgy and the semiconductor industry at high temperatures [36-41]. To our knowledge, the characterization of $\mathrm{HfO}_{2}$-based materials at temperatures lower than $500^{\circ} \mathrm{C}$ has not yet been conducted. 
The aims of this paper are to provide the new experimental results of oxygen probing in molten sodium using yttria-doped hafnia, to compare the performance of this probe with thoria and zirconia probes and to analyze the sources of discrepancies between the experimental results and the expected values.

\section{Fundamental Principles of a Potentiometric Sensor for Oxygen Analysis in Molten Sodium}

The fundamental principles of potentiometric sensors based on solid electrolytes have been reviewed in several papers [42-45]. Potentiometric sensors are based on the existence of an equilibrium at both of a sensor's interfaces. Let us consider, for example, an oxygen sensor for the measurement of the oxygen activity in liquid sodium:

$$
\begin{gathered}
\alpha \\
\mathrm{Me}(\mathrm{I}), \mathrm{O}_{2}(\mathrm{Ref}) / / \text { Solid oxide electrolyte }(\mathrm{SE}) / /((\mathrm{O}))_{\mathrm{Na}}, \mathrm{Na}, \mathrm{Me}(\mathrm{II})
\end{gathered}
$$

The reference can be a gas, such as air $\left(\mathrm{P}\left(\mathrm{O}_{2}\right)=0.2 \mathrm{bar}\right)$, or a metal/metal oxide mixture, such as $\mathrm{Cu} / \mathrm{Cu}_{2} \mathrm{O}, \mathrm{Na} / \mathrm{Na}_{2} \mathrm{O}$ or $\mathrm{In} / \mathrm{In}_{2} \mathrm{O}_{3}$. The terminal metallic lead, $\mathrm{Me}(\mathrm{I})$ and $\mathrm{Me}(\mathrm{II})$ are identical.

At interfaces $\alpha$ and $\beta$, the equilibrium can be written (using Kröger-Vink notation) as follows:

- Reference electrode (interface $\alpha$ ): $\quad 1 / 2 O_{2}^{\text {Ref }}+2 \mathrm{e}^{\prime}+V_{O}^{\bullet \bullet}=O_{O}^{\times}$

- Measuring electrode (interface $\beta)$ : $\quad((\mathrm{O}))_{\mathrm{Na}}+2 \mathrm{e}^{\prime}+V_{O}^{\bullet \bullet}=O_{O}^{\times}$

The equilibrium condition requires that no net current is passing through the cell [46], which contradicts the assumption of Nollet et al. [33] that there is an oxygen transfer from right to left in the cell. It should be noted that when considering an ideal solid electrolyte that is a pure ionic 
conductor, the electroneutrality condition within the oxide impedes any transfer of matter through the electrolyte.

Equilibrium reactions 1 and 2 lead to the following equation:

At interface $\alpha, 1 / 2 \mu_{O_{2}}^{R e f, \alpha}+2 \tilde{\mu}_{e^{\prime}}^{M e(I), \alpha}+\tilde{\mu}_{V_{O}^{* *}}^{S E, \alpha}=\mu_{O_{O}^{\times}}^{\alpha}$

where $\mu$ is the chemical potential and $\tilde{\mu}$ is the electrochemical potential; the exponent is the corresponding interface and the subscript is the chemical species.

Equation 3 leads to the following equation:

$$
\frac{R T}{2} \ln P_{O_{2}}^{R e f}+2 \mu_{e^{\prime}}^{M e(I), \alpha}+\mu_{V_{O}^{*}}^{S E, \alpha}-2 \mathrm{~F} \phi^{M e(I), \alpha}+2 \mathrm{~F} \phi^{S E, \alpha}=\mu_{O_{O}^{\times}}^{\alpha}
$$

where $\Phi$ is the electrical potential.

At interface $\beta, \mu_{((O))_{N a}}+2 \tilde{\mu}_{e^{\prime}}^{N a, \beta}+\tilde{\mu}_{V_{o}^{*}}^{S E, \beta}=\mu_{O_{O}^{\times}}^{\beta}$

It can be assumed that $\tilde{\mu}_{e^{\prime}}^{N a, \beta}=\tilde{\mu}_{e^{\prime}}^{M e(I I)}$; consequently, equation 5 becomes

$$
\mathrm{RT} \ln a_{((O))_{N a}}+2 \mu_{e^{\prime}}^{M e(I I)}+\mu_{V_{o}^{\circ}}^{S E, \beta}-2 \mathrm{~F} \phi^{M e(I I)}+2 \mathrm{~F} \phi^{S E, ß}=\mu_{O_{O}^{\times}}^{\circledR}
$$

Consequently, the emf of the cell can be written as follows:

$$
\mathrm{E}_{\mathrm{th}}=\frac{R T}{2 F} \ln a_{((O))_{N a}}-\frac{R T}{4 F} \ln P_{O_{2}}^{R e f}+\left(\phi^{S E, \beta}-\phi^{S E, \alpha}\right)+\frac{1}{2 F}\left(\mu_{V_{O}^{*}}^{S E, \beta}-\mu_{V_{O}^{*}}^{S E, \alpha}\right)
$$

The theoretical Nernst law,

$$
\mathrm{E}_{\mathrm{th}}=\frac{R T}{4 F} \ln \frac{a_{((o))_{N a}}^{2}}{P_{O_{2}}^{R e f}}
$$


is obeyed, assuming two hypotheses:

- The electrical potential is constant within the solid electrolyte $\left(\phi^{S E, \beta}=\phi^{S E, \alpha}\right)$, thus avoiding any dc current through the cell and leading to an ohmic drop.

- The chemical potential of oxygen vacancies on both sides of the electrolyte wall are identical $\left(\mu_{V_{O}^{*}}^{S E, \beta}=\mu_{V_{O}^{*}}^{S E \alpha}\right)$.

In essence, the cell emf results from surface thermodynamics and not bulk thermodynamics, as has sometimes been considered [33].

Because dissolved oxygen in sodium is exclusively in the form of $\mathrm{Na}_{2} \mathrm{O}$, its oxygen activity $a_{((O))_{N a}}$ can be replaced by $a_{\left(\left(\mathrm{Na}_{2} O\right)\right)_{N a}}$. Owing to the low concentrations of oxygen observed in sodium, it can be assumed that the activity coefficients remain constant (Henry's law). Consequently, assuming solid sodium oxide $\mathrm{Na}_{2} \mathrm{O}$ as the standard state for the oxygen in molten sodium, the activity of oxygen can be defined as [47]:

$$
a_{\left(\left(\mathrm{Na} a_{2} \mathrm{O}\right)\right)_{N a}}=\frac{C_{\left(\left(\mathrm{Na} a_{2} \mathrm{O}\right)\right)_{N a}}}{C_{\left(\left(\mathrm{N} a_{2} \mathrm{O}\right)\right)_{N} a}^{O}}
$$

where $C_{\left(\left(\mathrm{Na}_{2} \mathrm{O}\right)\right)_{\mathrm{Na}}}$ is the actual $\mathrm{Na}_{2} \mathrm{O}$ concentration in sodium and $C_{\left(\left(\mathrm{Na}_{2} \mathrm{O}\right)\right)_{\mathrm{Na}}}$ is the $\mathrm{Na}_{2} \mathrm{O}$ concentration in equilibrium with solid $\mathrm{Na}_{2} \mathrm{O}$.

According to equation 8 , the theoretical emf of the cell becomes

$$
\mathrm{E}_{\mathrm{th}}=\frac{R T}{2 F} \ln \frac{C_{\left(\left(\mathrm{Na} a_{2} O\right)\right)_{N a}}}{C_{\left(\left(\mathrm{N} a_{2} O\right)\right)_{N a}}^{o}}-\frac{R T}{4 F} \ln P_{O_{2}}^{R e f}
$$

In the case of using a metal/metal oxide reference system, such as $\operatorname{In} / \operatorname{In}_{2} \mathrm{O}_{3}$, $\mathrm{E}_{\text {th }}$ is

$$
\mathrm{E}_{\text {th }}=\frac{R T}{2 F} \ln C_{\left(\left(N a_{2} \mathrm{O}\right)\right)_{N a}}-\frac{R T}{2 F} \ln C_{\left(\left(N a_{2} \mathrm{O}\right)\right)_{N a}}^{o}-\frac{\Delta_{f} G^{\circ}\left(\operatorname{In}_{2} \mathrm{O}_{3}\right)}{6 F}
$$

where $\Delta_{f} G^{\circ}\left(\operatorname{In}_{2} O_{3}\right)$ is the Gibbs energy of the formation of $\operatorname{In}_{2} \mathrm{O}_{3}$. 


\section{Sources of Error}

According to the experimental conditions, many sources of error can induce deviation from the theoretical emf $\left(E_{t h}\right)$. The main sources of error in an oxygen sensor used in extreme conditions, such as the measurement of the oxygen activity in liquid sodium at low temperatures, are described in detail in this section.

The most common source of error results from a small current passing through the cell. As is discussed later, this current induces a polarization voltage $\eta$, i.e., the measured cell emf is equal to

$$
\mathrm{E}=\mathrm{E}_{\mathrm{th}}+\eta
$$

This polarization phenomenon is not always considered in the literature, although it has been demonstrated experimentally that the sensor surfaces can deviate largely from equilibrium [48, 49]. Various models have been developed to estimate the polarization voltage $\eta$. For very low currents, the polarization voltage can be considered as proportional to the current density i [50]:

$$
\eta=E-E_{t h}=R_{p} \cdot i
$$

$\mathrm{R}_{\mathrm{p}}$ is defined as the polarization resistance.

For higher currents, a Butler-Volmer-like model can be referred to as follows [51-53]:

$$
\eta=\mathrm{E}-\mathrm{E}_{\mathrm{th}}= \pm \frac{R T}{n F} \ln \frac{i}{i^{\circ}}=\mathrm{a} \pm \mathrm{b} \cdot \log \mathrm{i}
$$

where $n$ is the number of electrons involved in the electrochemical reaction and $i^{\circ}$ is the exchange current density that defines the reversibility of the electrode reaction and $\mathrm{a}$ and $\mathrm{b}$ are 
kinetic parameters [54]. It should be noted that a very low current can induce high polarization voltages [55].

\subsection{Insufficient Input Impedance of the Millivoltmeter}

If the millivoltmeter used for the measurement of the cell emf exhibits an input impedance that is too low compared to the impedance of the cell, a small current is passing through the sensor. This has two main consequences:

- A deviation from the theoretical emf due to an ohmic drop through the electrolyte $\left(\phi^{S E, ß}-\phi^{S E, \alpha} \neq 0\right)$; see equation 7 ;

- A polarization phenomenon at one or both electrodes due to the current [56].

This phenomenon can be considered as negligible with the high input impedance millivoltmeter $(>10 \mathrm{G} \Omega)$ used presently [33].

\subsection{Partial Electronic Conductivity of the Electrolyte}

As previously stated, the Nernst law requires that the electrolyte is a pure ionic conductor. However, electronic species (electrons or electron holes) may be present due to equilibria between the oxide and the electrode systems:

- At high oxygen partial pressure, oxygen is incorporated into the oxide, inducing a ptype additional conductivity:

$$
1 / 2 \mathrm{O}_{2}+V_{O}^{\bullet \bullet} \rightarrow O_{O}^{\times}+2 \mathrm{~h}^{\bullet}
$$

- At low oxygen pressure, a loss of oxygen from the lattice occurs, inducing an n-type conductivity: 


$$
O_{O}^{\times} \rightarrow 1 / 2 \mathrm{O}_{2}+V_{O}^{\bullet \bullet}+2 \mathrm{e}^{\prime}
$$

The ionic transport number $t_{i}$ is defined as the ratio of the ionic conductivity $\sigma_{i}$ over the total conductivity. The region $\left(\mathrm{P}\left(\mathrm{O}_{2}\right), \mathrm{T}\right)$ of predominantly ionic conduction $\left(\mathrm{t}_{\mathrm{i}}>0.99\right)-$ generally termed the "electrolytic domain" - has been delineated at high temperatures for the most-used oxide electrolytes [57-60]. It has been shown that a thoria-based electrolyte in contact with air is outside the electrolytic domain, which is not the case for yttria-stabilized zirconia [33, 61]. In contrast, in contact with sodium, a thoria-based electrolyte is inside the electrolytic domain, which is not the case for zirconia. It should be noted that the boundary lines of the electrolytic domains are strongly influenced by the impurity content of the electrolyte [62]. Moreover, the electrolytic domain gives only an indication of the stability of the electrolyte; a noticeable error of measurement may be observed even with an electronic transport number smaller than $1 \%$.

The additional electronic conductivity of the electrolyte induces three main sources of error [42]:

- According to Wagner's theory, and considering a mean ionic transport number $\bar{t}_{i}$, the open-circuit voltage $\mathrm{E}$ is given by the following equation:

$$
\mathrm{E}=\bar{t}_{i} \cdot \mathrm{E}_{\mathrm{th}}
$$

- The additional electronic conductivity induces an oxygen semipermeability flux through the electrolyte, which can change the oxygen chemical potential at one or both electrodes of the cell.

- The oxygen semipermeability flux polarizes the electrodes [55, 63]; see equations 13 and 14 .

\subsection{Insufficient Buffer Capacity}


The measurement error due to an oxygen semipermeability flux or to impurities in the measuring or the reference system, etc., depends not only on the magnitude of the perturbation but also on the buffer capacity at the electrode $[64,65]$. The buffer capacity of a gas mixture can be defined as the number of moles of oxygen required to increase the chemical potential by $1 \mathrm{~kJ}$ per mole of gas mixture. As an example, it has been demonstrated that the buffer capacity is high for oxygen pressures higher than $10^{-5}$ bar for an $\mathrm{Ar}-\mathrm{O}_{2}$ mixture and lower than $10^{-10} \mathrm{bar}$ for a $\mathrm{CO}-\mathrm{CO}_{2}-\mathrm{O}_{2}$ mixture. In these ranges of oxygen partial pressure, the effect of some perturbation is successfully eliminated by the system. Using an electrochemical concept, the buffer capacity can be related to the exchange current density defined previously (see equation 11). A redox system with a high exchange current density will be less sensitive to perturbations. In this context, it is well-known that a $\mathrm{Ni} / \mathrm{NiO}$ reference system is much more sensitive to perturbations than $\mathrm{Cu} / \mathrm{Cu}_{2} \mathrm{O}$ or $\mathrm{Fe} / \mathrm{FeO}$ reference mixtures [66]. The partial oxidation of the molybdenum current lead with a $\mathrm{Bi} / \mathrm{Bi}_{2} \mathrm{O}_{3}$ reference mixture has been considered as responsible for emf drift and instabilities in the signal of potentiometric sensors [67].

\subsection{Corrosion Phenomenon at the Electrolyte Surfaces}

When an active species dissolved in a liquid is in contact with a solid electrolyte, it can penetrate into the bulk by ionic exchange, inducing a measurement error that has been well-studied in the case of ion-selective electrodes [68]. The thermodynamic stability domain of an oxide electrolyte membrane, such as yttria-stabilized zirconia in contact with sodium, can be studied using the oxobasicity concept $[69,70]$. As an example, due to the presence of $\mathrm{Na}_{2} \mathrm{O}$, the molten sodium can be considered as oxobasic. In these conditions, the yttria stabilizer is liable to be dissolved [71]:

$$
\mathrm{Y}_{2} \mathrm{O}_{3}+\mathrm{O}^{2-}=2 \mathrm{YO}_{2}^{-}
$$


The resulting depletion of yttrium near the surface of the membrane induces a noticeable modification of the zirconia structure, with the appearance of monoclinic and/or tetragonal phases. In these conditions, the oxide vacancy concentration is no longer identical at both interfaces of the membrane $\left(\mu_{V_{O}^{*}}^{S E, \beta} \neq \mu_{V_{O}^{\circ}}^{S E, \alpha}\right.$; see equation 7), inducing a measurement error. Besides this, the oxide electrolyte becomes very brittle.

\subsection{Measurement of a Mixed Potential Instead of a Thermodynamic emf}

Owing to impurities in molten sodium or by-products resulting from the corrosion of the structural materials of the circuits of fast reactors, more than one redox couple may be present at the interface between the solid electrolyte and sodium. In these conditions, the measured emf of the cell is not a thermodynamic voltage but a mixed potential, $\mathrm{E}_{\text {mixed, }}$ which widely depends on the exchange current densities $\mathrm{i}^{\circ}$ of the involved electrochemical systems [72]. The mixed potential takes an intermediate value between the potential of both systems. However, as illustrated in Figure 1, the mixed potential is close to the potential of the couple that exhibits the highest exchange rates.

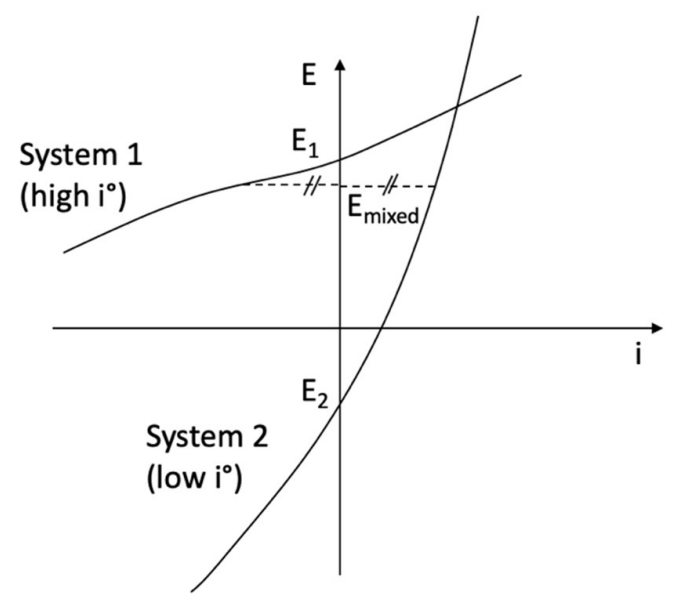

Figure 1: Mixed potential in the case of two electrochemical reactions at the interface exhibiting very different exchange current densities.

\subsection{Partially Reduced Electrolyte}


The partial reduction of an oxide electrolyte results in a valence change either of the basic cation $\left(\mathrm{Zr}^{4+}\right.$ in the case of zirconia, $\mathrm{Th}^{4+}$ in the case of thoria-based oxides) or of a point defect (a dissolved impurity, such as ferric ions, or a structural defect, such as oxide ion vacancies). Such a reduction can be obtained by electrochemical reduction or by equilibrating the material with a reducing system. An experimental method has been developed by Fabry et al. [73] to determine the voltages that characterize the dissolved redox system in an oxide electrolyte; this method is described in section 4.2. Figures 2 and 3 show the various redox potentials that were previously determined in yttria-stabilized zirconia and yttria-doped thoria.

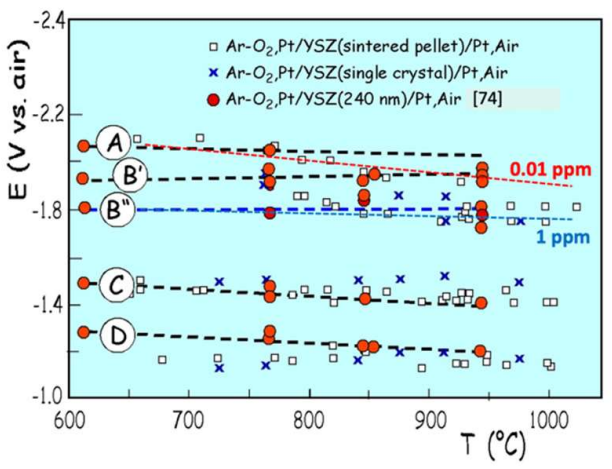

Figure 2: Reoxidation potentials of yttria-stabilized zirconia as a function of temperature. Results obtained by Fabry et al. on sintered pellets and on single crystals [73] and by Boulfrad et al. on nanostructured zirconia [74]. The variation of the theoretical sensor emf vs. air for 0.01 and $1 \mathrm{ppm}$ of oxygen in sodium is plotted in the figure.

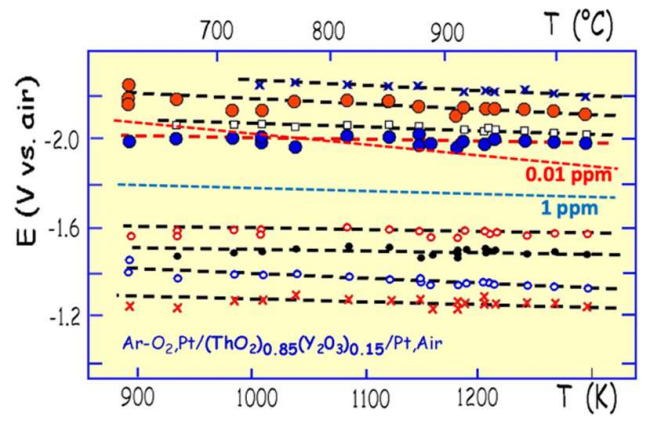

Figure 3: Reoxidation potentials of yttria-doped thoria as a function of temperature. Results obtained by Fabry [75]. The variation of the theoretical sensor emf vs. air for 0.01 and $1 \mathrm{ppm}$ of oxygen in sodium is plotted in the figure.

It has been shown that when dealing with stabilized zirconia, besides the main reduction corresponding to the valence change of $\mathrm{Zr}^{4+}$ ions, which occurs at approximately $-2.05 \mathrm{~V} / \mathrm{Air}$ (wave A in Figure 2), three additional point defects, such as oxygen vacancies or dissolved impurities, can be reduced. This results in a macroscopic chemical reduction of the material, inducing a blackened oxide (redox potentials labeled with B', B' and C in Figure 2). Waves B' and B" have been ascribed to the reduction of oxygen vacancies; wave C was related to the trapping of electrons on impurities, or on oxygen vacancies in the vicinity of an impurity, or on a vacancy involved in a cluster of point defects [74]. The reduction that occurs near -1.2 V/air 
(referred to as D) has an extremely small magnitude and is limited to the surface or subsurface area (formation of superficial carbon compounds). As shown in Figure 3, in thoria-based oxides, many reduction waves have been observed, attributed to impurities dissolved in the ceramic [75]. However, Fabry has shown that the dissolved redox systems are reduced below $-2 \mathrm{~V} /$ Air; the waves observed at potentials higher than -1.6 V/Air do not involve redox couples inducing a noticeable increase of the electronic conductivity of the bulk material. In both figures, the variation of the theoretical sensor emf versus air for 0.01 and $1 \mathrm{ppm}$ of oxygen in sodium is plotted. For an oxygen level of $1 \mathrm{ppm}$ in molten sodium, the cell voltage is in the order of $-1.8 \mathrm{~V} /$ Air. Consequently, when in contact with sodium, zirconia is reduced, leading to blackened zirconia [76] (potential C in Figure 2). On the other hand, bulk thoria electrolyte is not reduced. In the case of the reduction of the electrolyte, provided that the buffer capacity is sufficient, the electrode potential is either fixed by the redox couple (such as $V_{o}^{\bullet \bullet} / V_{O}^{\bullet}$ ), or results from a mixed potential with a redox system dissolved in molten sodium (see section $3.5)$.

\subsection{Very Low Operating Temperature}

To avoid or reduce the corrosion of the electrolyte by sodium, the working temperature of the oxygen sensor is low, i.e., below $400^{\circ} \mathrm{C}$, which has various consequences:

- The impedance of the cell increases noticeably. Even if the total resistance of the cell does not interfere with the calculation of the Nernst law, it is necessary that the total impedance remains negligible with respect to the input impedance of the millivoltmeter, as previously stated. As an example, poor contact between the reference system and the electrolyte has no influence on the cell emf but may induce instabilities of the cell voltage. 
- The exchange rates of the oxygen electrode reactions at the solid electrolyte/sodium interface, but also at the reference/electrolyte interface, may be dramatically low.

- The buffer capacity of the main electrode reaction diminishes; consequently, the measuring electrode becomes more sensitive to perturbations.

- The oxygen electrode reaction may be of a different nature. In an oxygen gas sensor, at high temperature, the oxygen electrode reaction involves four electrons per mole of oxygen:

$$
\mathrm{O}_{2}+4 \mathrm{e}^{-}=2 \mathrm{O}^{2-}
$$

However, at low temperature, the electrochemical reaction does not require the full oxidation or reduction of the reactive species [77]. The electrode reaction can be schematically written as follows:

$$
O_{2} \stackrel{k_{1}}{\rightarrow} O_{2}^{2-} \stackrel{k_{2}}{\rightarrow} 2 O^{2-}
$$

At high temperatures, the rate constant $\mathrm{k}_{2}$ is higher than $\mathrm{k}_{1}$ and the overall reaction (equation 19) is observed. At low temperatures, the constant $\mathrm{k}_{2}$ becomes lower than $\mathrm{k}_{1}$ and the overall reaction rate is dominated by step 2 and appears to be slower than the partial reaction (1), which reaches equilibrium more rapidly. Still decreasing the temperature, the constant $\mathrm{k}_{2}$ may become nil and the second step will no longer be observed. Various studies have demonstrated that at low temperatures, the number of electrons involved in the oxygen reaction is lower than four (most often two), corresponding to the overall electrode reaction, in which peroxide ions are involved [78-81]:

$$
\mathrm{O}_{2}+2 \mathrm{e}^{-}=\mathrm{O}_{2}^{2-}
$$

Provided that the peroxide ion activity remains constant, the Nernst law obeys the following equation: 


$$
E_{t h}=K+\frac{R T}{2 F} \ln \frac{P_{O_{2}}}{P_{O_{2}}^{R e f}}
$$

where $\mathrm{K}$ is a constant.

This feature - which has not yet been considered in sensing oxygen dissolved in molten sodium - is discussed in further detail in the discussion section of this paper.

\section{Experimental Section}

Two types of sensors were tested: some results concern an yttria-doped thoria oxygen meter provided by UKEA-Harwell (MK IIA sensor), which has been widely characterized by Taylor and Thompson [11, 14], and the remainder relate to a laboratory-made hafnia-based sensor.

\subsection{Yttria-Doped Thoria (YDT) Oxygen Sensors}

The MK IIA-type sensors were purchased from UKEA-Harwell (Oxon) and have been described by Taylor and Thompson $[11,14]$. The sensors were closed-ended YDT tubes and were $160 \mathrm{~mm}$ long and $6.5 \mathrm{~mm} \mathrm{OD}$, with an internal metal/metal oxide reference electrode $\left(\mathrm{Sn} / \mathrm{SnO}_{2}\right.$ or $\left.\mathrm{In} / \mathrm{In}_{2} \mathrm{O}_{3}\right)[82]$. The tests of the YDT sensor were performed in a sodium stainless steel loop (EPINAR, ca. 3 t. Na). The procedure has been described in detail by Taylor and Thompson $[11,14]$. The cold-trap temperature was controlled by a combination of furnace heating and air cooling. The tests included changing cold-trap temperatures to a cycle and the measurement of the cell emf. The cold-trap changing cycle took approximately seven days and consisted of raising the temperature of the cold-trap from $105-200^{\circ} \mathrm{C}$ in $15-30^{\circ} \mathrm{C}$ steps. The system was left to equilibrate for 24 hours after each cold-trap temperature step. From this procedure, the calibration equation for each cell was determined, relating cell output voltage to cold-trap temperature. The oxygen concentration in sodium within the loop was supposed to be in equilibrium at the cold-trap temperature. 


\subsection{H10Y Sensors}

\subsubsection{Fabrication of H10Y Sensors}

After a preliminary study of the $\mathrm{HfO}_{2}-\mathrm{Y}_{2} \mathrm{O}_{3}$ solid solutions (between 0.5 and 15 mol. $\% \mathrm{Y}_{2} \mathrm{O}_{3}$ ), the composition $\mathrm{HfO}_{2}-10$ mol. $\% \mathrm{Y}_{2} \mathrm{O}_{3}$ (referred to as $\mathrm{H} 10 \mathrm{Y}$ ) was chosen because it presents the best compromise in terms of purity of the phase, density after sintering, resistance to corrosion by liquid sodium, etc. The synthesis of the $\mathrm{H} 10 \mathrm{Y}$ powder was carried out by impregnation $\left(\mathrm{HfO}_{2}\right.$ powder provided by AREVA-CEZUS + yttrium nitrate under ethanol), drying under agitation and the decomposition of nitrate by calcination $\left(800^{\circ} \mathrm{C}, 4 \mathrm{~h}\right)$. The pellets were pressed uniaxially $\left(0.5 \mathrm{ton} / \mathrm{cm}^{2}\right)$, followed by cold isostatic pressing at 2500 bars. Their sintering was then carried out at $1650{ }^{\circ} \mathrm{C}$ for $4 \mathrm{~h}$. under air after a temperature rise of $120^{\circ} \mathrm{C} / \mathrm{h}$. After sintering, the grain size was ca. $1-2 \mu \mathrm{m}$. As shown in Figure 4, the XRD analysis of the as-sintered ceramic confirmed that only the cubic phase is present with small traces of a monoclinic phase.

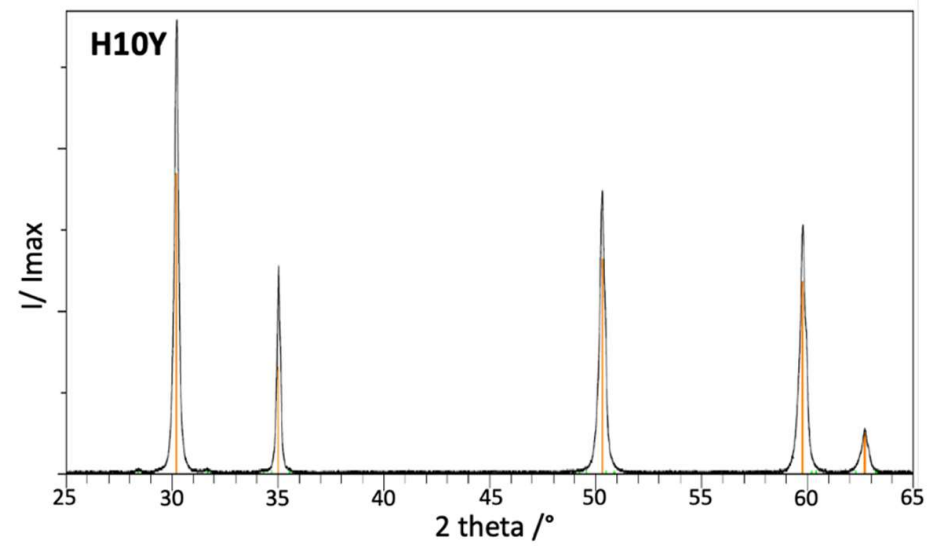

Figure 4: XRD pattern of the H10Y sintered pellets.

Closed-ended tubes $(10 \mathrm{~mm}$ in diameter and $45 \mathrm{~cm}$ in length) were fabricated at the Center for Technology Transfers in Ceramics (CTTC) in Limoges, France, by an isostatic pressing method and sintering at $1650{ }^{\circ} \mathrm{C}$ for $2 \mathrm{~h}$. The concentrations of the main impurities, measured by GD-MS (after grinding and pelletization with pure $\mathrm{Ag}$ powder) were as follows: $\mathrm{SiO}_{2}$ ca. $0.0043 \%$ wt.; $\mathrm{CaO} 0.002 \%$; 
$\mathrm{Fe}_{2} \mathrm{O}_{3}$ 0.004\%; and $\mathrm{Na}_{2} \mathrm{O}$ 0.0012\%. The sensor assembly, schematized in Figure 5, has been described in previous publications, [83-85]. Mo was used as a lead wire $(0.5 \mathrm{~mm}$ in diameter, $99.95 \%$ purity, supplied by Goodfellow). The inner reference was a mixture of In as shoots of $15 \mathrm{~mm}$ of $99.999 \%$ purity cut into small pieces, supplied by Goodfellow $(4 \mathrm{~g})$ and $\mathrm{In}_{2} \mathrm{O}_{3}$ powder of $99.99 \%$ purity supplied by Chempur $(0.4 \mathrm{~g})$. At operating temperature, the metal part of the metal/metal oxide mixture was liquid, which improved the contact with the electrolyte. The junction between the ceramic tube and the connecting steel tube was realized by an alumina cement, which was not intended to be in contact with the liquid sodium.

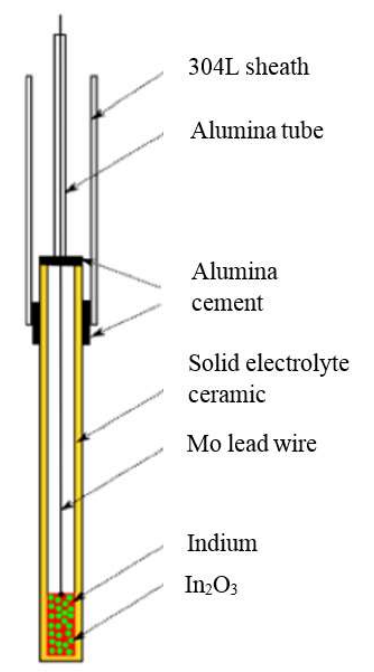

Figure 5: Tested oxygen sensors.

\subsubsection{Electrochemical Stability of $\mathrm{H} 10 \mathrm{Y}$}

The method used to determine the potentials at which the electrochemical reduction of the electrolytes occurs was first proposed by Fabry et al. [73] and adapted for the study of various oxides [74, 86-88]. The laboratory-made rig that was used is shown in Figure 6 and described in further detail elsewhere [74]. The cell consists of an 8YSZ tube (10 $\mathrm{mm}$ in external diameter), with the outer surface of a closed end painted with platinum paste (METALOR Pt ink 6926). Air was used as the reference atmosphere. Dense yttria-doped hafnia pellets were shaped into 
small cylinders. A platinum lead wire was inserted on the top of the small cylinder and used as a measuring electrode. The probe was placed in contact with the inner surface of the closed end of the zirconia tube. Argon was used as a sweep gas along the internal chamber, while the opencircuit voltage (OCV) of the cell with respect to the air reference electrode (E/Air) was measured (Figure 6 a). Basically, the method involved electrochemically reducing the top of the small cylinder of the investigated material by applying an appropriate voltage to the cell. The applied voltage and the reduction time were chosen so that only the top of the small cylinder was reduced, avoiding the electrochemical reduction of the zirconia tube. After interrupting the current, the relaxing OCV of the cell with respect to the reference electrode was recorded during the slow reoxidation of the reduced material by the traces of oxygen contained in the argon. Figure $6 \mathrm{~b}$ shows an example of the recorded relaxation potential of the point electrode versus air for a 10 mol.\% yttria-doped hafnia sample. The depolarization curves show waves whose inflection points (referred to as A, B and D, respectively) are characteristic of dissolved or surface redox systems.

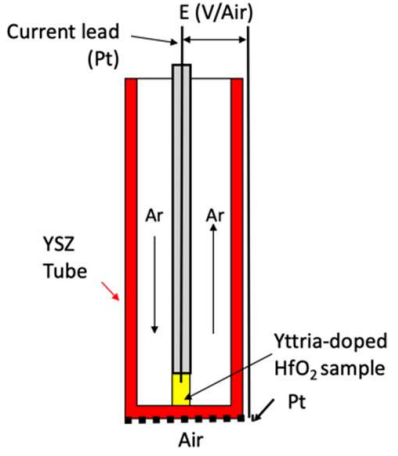

(a)

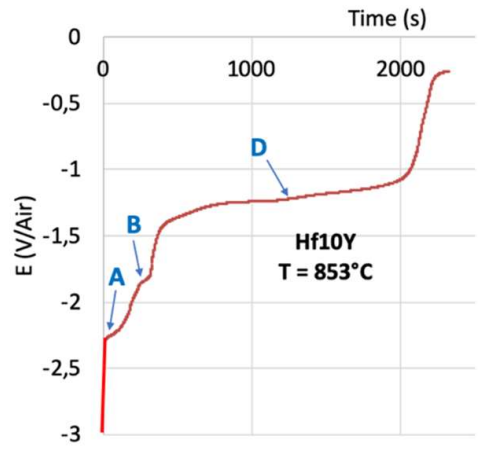

(b)

Figure 6: (a) Schematic drawing of the setup for the evaluation of the redox stability of yttria-doped hafnia; (b) Representation of a typical reoxidation curve after electrochemical reduction of Hf10Y, obtained by recording the OCV of the cell with respect to the air reference electrode (E(V/Air)).

\subsubsection{Setup}


As schematized in Figure 7, an internal crucible made of pure Ni (Ni201) filled with ca. 0.26 $\mathrm{kg}$ of liquid sodium (11 mol.) was used as a container. A K-type thermocouple inserted in an immersion sleeve made of 304-grade stainless steel monitored the liquid sodium temperature. A leak-tight stainless steel cell holder was filled with argon, heated by a heating collar and cooled on the top with cooling fins and a blower to keep the seal close to room temperature. A feedthrough was provided in the lid of the cell holder for the introduction of the oxygen sensor. This setup was set inside an argon purified glove box to ease all sodium-related operations before and after the experiments. Accurate measurement of the sensor emf was performed with a Keithley 6517B electrometer, and signal and temperature were recorded with an Agilent 39740A datalogger.

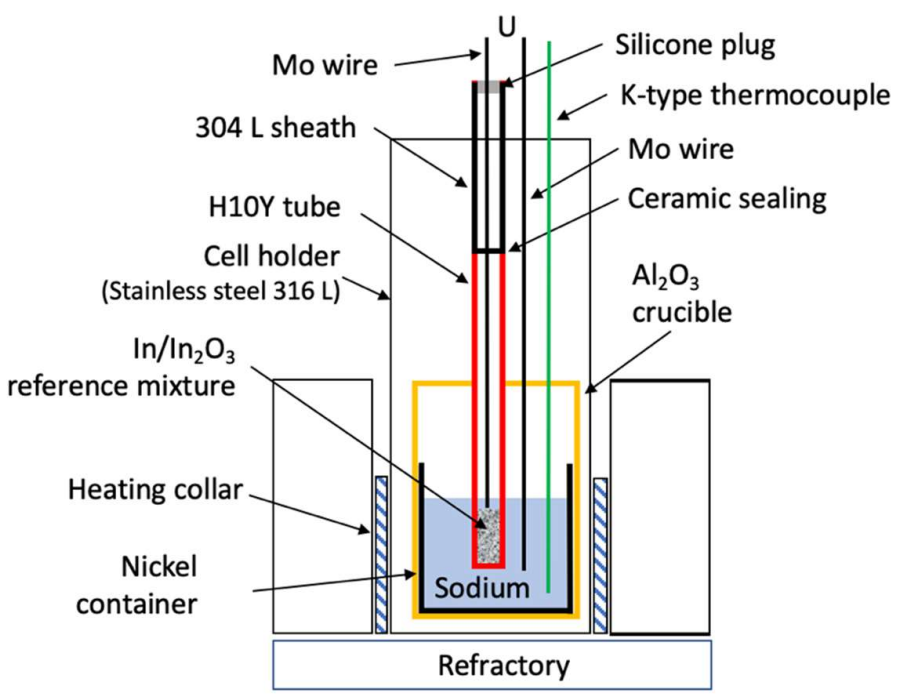

Figure 7: Schematic of the electrochemical setup.

\subsubsection{Liquid Sodium Preparation and Operating Conditions}

The sodium used for the tests was supplied by Métaux Spéciaux S.A. The sodium was 99.95 wt. \% pure, containing [Ca] $2 \mu \mathrm{g} \cdot \mathrm{g}^{-1},[\mathrm{Cl}]=4 \mu \mathrm{g} \cdot \mathrm{g}^{-1}$, $[\mathrm{Fe}]=1 \mu \mathrm{g} \cdot \mathrm{g}^{-1}$ and $[\mathrm{K}]=4 \mu \mathrm{g} \cdot \mathrm{g}^{-1}$. It also contained $\mathrm{C}$ and was initially covered with a thick sodium oxide layer. This layer was manually removed inside a glove box filled with argon before the first melt, which was achieved 
in another static sodium device used for corrosion studies [89, 90]. Next, $2.3 \mathrm{~kg}$ of sodium was purified from dissolved oxygen, first by removal of the floating oxides after three days at $108^{\circ} \mathrm{C}$, close to the melting temperature, and then through hot-trapping by immersing zirconium foil $\left(200 \times 300 \times 0.1 \mathrm{~mm}^{3}\right)$ at $650^{\circ} \mathrm{C}$ for three days. The oxygen concentration was then estimated to be less than $1 \mu \mathrm{g} \cdot \mathrm{g}^{-1}$ [91]. Although this last purification step is known to remove dissolved carbon from sodium, previous tests have indicated that the dissolved carbon concentration is not negligible. A sensor was inserted in the still solid sodium at $80^{\circ} \mathrm{C}$ when the metal softened and the temperature was then increased at a low rate to limit any thermal shocks.

The tests were performed in a temperature range of $200-300^{\circ} \mathrm{C}$ with liquid sodium melt containing an excess of zirconium getter in the form of thin foil. The test consisted of varying the temperature according to a defined rate $\left(1.5^{\circ} \mathrm{C} / \mathrm{min}\right.$ and $\left.0.1^{\circ} \mathrm{C} / \mathrm{min}\right)$ up to ca. $300^{\circ} \mathrm{C}$ and then back to $200^{\circ} \mathrm{C}$, and the signal output versus temperature and time was then recorded. Adding holding times of at least $8 \mathrm{~h}$ for the lowest rate of $0.1^{\circ} \mathrm{C} / \mathrm{min}$ was found to be optimal to obtain reliable signal variation with the temperature. Small oxygen concentrations and low temperature conditions were deliberately chosen to increase the service lifetime of the sensor in order to be able to perform qualification tests. This choice allowed testing over more than $1,000 \mathrm{~h}$.

\section{Results}

\subsection{Theoretical emf of the Sensors}

The theoretical sensor emf $\left(\mathrm{E}_{\mathrm{th}}\right)$ versus the $\mathrm{T}$ (in $\mathrm{K}$ ) relationship was calculated using equation 11 and the data presented in Table 1.

Table 1: Thermodynamic data.

\begin{tabular}{|l|l|l|}
\hline & A + B.T & Reference \\
\hline$\Delta_{\mathrm{f}} \mathrm{G}^{\mathrm{o}}\left(\mathrm{In}_{2} \mathrm{O}_{3}\right)\left(\mathrm{kJ} / \mathrm{mol} \mathrm{O}_{2}\right)$ & $-618.67+0.217 \times \mathrm{T}_{\mathrm{K}}$ & {$[92]$} \\
\hline$\Delta_{\mathrm{f}} \mathrm{G}^{\mathrm{o}}\left(\mathrm{Na}_{2} \mathrm{O}\right)\left(\mathrm{kJ} / \mathrm{mol} \mathrm{O}_{2}\right)$ & $-843.21+0.283 \times \mathrm{T}_{\mathrm{K}}$ & {$[92]$} \\
\hline
\end{tabular}


The relationship of the logarithmic dependence of oxygen concentration on the temperature in liquid sodium at saturation has been proposed by Noden [93]:

$$
\operatorname{Ln} C_{\left(\left(N a_{2} \mathrm{O}\right)\right)_{N a}}^{o}\left(\text { wt. \%) }=5.20-5628.67 / \mathrm{T}_{\mathrm{K}}\right.
$$

Using equation 11, the emf of the sensor $\mathrm{E}_{\text {th }}$ becomes

$\mathrm{E}_{\mathrm{th}}(\mathrm{mV})=\mathrm{K}_{1}+\mathrm{K}_{2} \mathrm{~T}+\mathrm{K}_{3} \mathrm{~T} \ln \mathrm{C}_{\mathrm{O}}=-339.3-0.051 \mathrm{~T}_{\mathrm{K}}+0.0431 \mathrm{~T}_{\mathrm{K}} \ln C_{\left(\left(N a_{2} O\right)\right)_{N a}}(\mathrm{wt} . \%)$.

We assume that the measured voltage $E$ equals $E_{\text {th }}+E_{\text {offset. }}$ Consequently,

$$
\begin{aligned}
& \mathrm{E}=\mathrm{E}_{\text {offset }}+\mathrm{K}_{1}+\mathrm{T}_{\mathrm{K}}\left(\mathrm{K}_{2}+\mathrm{K}_{3} \ln C_{\left(\left(N a_{2} \mathrm{O}\right)\right)_{N a}}\right) \\
& \mathrm{E}(\mathrm{mV})=\mathrm{E}_{\text {th }}+\mathrm{E}_{\text {offset }} \\
& \mathrm{E}(\mathrm{mV})=\mathrm{E}_{\text {offset }}-339.3+\mathrm{T}_{\mathrm{K}}\left(-0.051+0.0431 \ln C_{\left(\left(\mathrm{Na}_{2} \mathrm{O}\right)\right)_{N a}}\right)
\end{aligned}
$$

The emf of the sensors was recorded after changing the temperature of the bath at a constant oxygen concentration or by changing the temperature of the cold-trap for monitoring the oxygen concentration.

\subsection{Test of the MK IIA YDT Sensor}

In Figure 8, the experimental emf of the MK IIA sensor with the $\operatorname{In} / \operatorname{In}_{2} \mathrm{O}_{3}$ reference system at $410^{\circ} \mathrm{C}$ is compared to the theoretical emf (equation 21 ) for various oxygen concentrations.

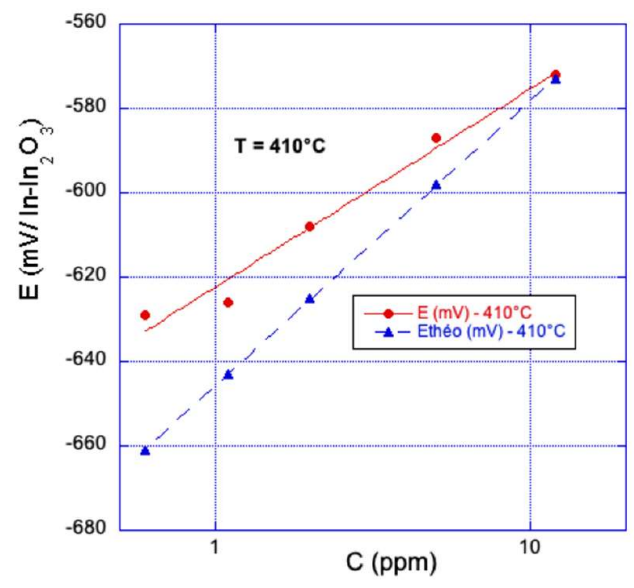

Figure 8: Calibration test of the MK IIA at $410^{\circ} \mathrm{C}$. 
Taylor and Thompson $[11,94]$ have noted that the temperature coefficients of the MK IIA probes are reproducible and in agreement with values calculated from thermodynamic data. These features allow the performance of the sensors to be characterized from the values of the interception of the emf at $0 \mathrm{~K}$ and by the offset values as functions of temperature and oxygen level. As shown in Figure 8, the observed offsets at $410^{\circ} \mathrm{C}$ from $32 \mathrm{mV}$ for $0.6 \mathrm{ppm}$ of oxygen to $1 \mathrm{mV}$ for $12 \mathrm{ppm}$ of oxygen, correspond to a measurement error of less than $5 \%$ on the measured emf. These offset values are of the same order of magnitude as those observed by Taylor and Thompson for an equivalent oxygen sensor (cell No 31/5), i.e., from $18 \mathrm{mV}$ for 1.2 ppm to $1 \mathrm{mV}$ for $28.4 \mathrm{ppm}$. These offsets are interpreted and compared to hafnia-based or zirconia-based sensors in the discussion section of this paper.

\subsection{Test of the H10Y Sensor}

Before proceeding with the tests of the H10Y sensor, we studied its electrochemical stability according to the method described in section 4.2.2.

As illustrated in Figure 6 b, three waves (referred to as A, B and D) were observed. According to previous studies on oxide materials, wave A could be attributed to the reduction of the basic cation $\left(\mathrm{Hf}^{4+}\right.$, potential of the wave at ca. $-2 \mathrm{~V} /$ Air at $\left.800^{\circ} \mathrm{C}\right)$ and wave $\mathrm{B}($ at $-1.75 \mathrm{~V} / \mathrm{Air}$ at $800^{\circ} \mathrm{C}$ ) could be attributed to the reduction of oxide ion vacancies. Wave D corresponds to surface defects or impurities segregated at the grain boundaries. The variation as a function of the temperature of the potential versus air of the waves is provided in Figure 9. As a means of comparison, the theoretical emf variation versus the temperature of an oxygen sensor (reference: air) for an oxygen content in sodium of 0.01 and $1 \mathrm{ppm}$ is also plotted in Figure 9. It is worth noting that by extrapolation at temperatures lower than $350^{\circ} \mathrm{C}$ of the potentials of waves $\mathrm{A}$ and $\mathrm{B}$, these potentials are more negative than the sensor emf versus air for an oxygen 
level higher than $0.01 \mathrm{ppm}$ in sodium. Consequently, at temperatures used for oxygen sensing in sodium, the hafnia-based electrolytes are electrochemically stable.

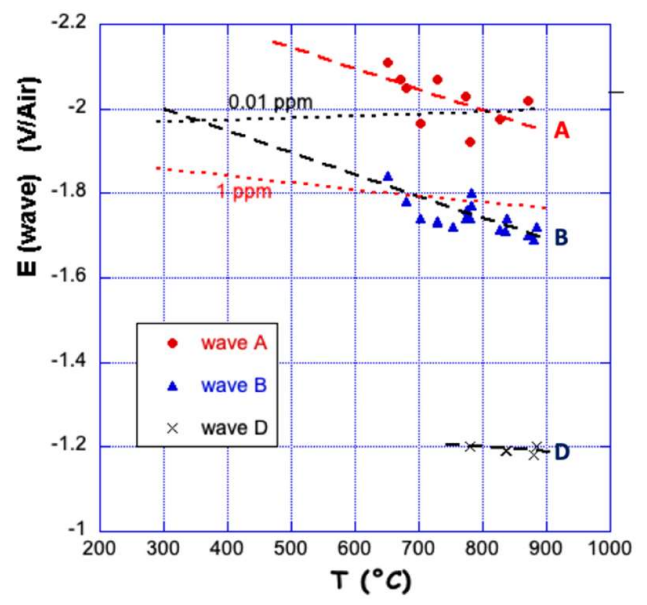

Figure 9: Reoxidation potentials of $\mathrm{HfO}_{2}-8 \mathrm{~mol} . \% \mathrm{Y}_{2} \mathrm{O}_{3}$ synthesized by CTTC-Limoges. The variation of the theoretical sensor emf vs. air for 0.01 and $1 \mathrm{ppm}$ of oxygen in sodium is plotted in the figure.

Figure 10 shows the variations of the sensor signal with the temperature according to the operating conditions, i.e., $1.5^{\circ} \mathrm{C} / \mathrm{min}, 0.1^{\circ} \mathrm{C} / \mathrm{min}$ and $0.1^{\circ} \mathrm{C} / \mathrm{min}$ followed by a holding time of at least eight hours. The theoretical variations of the sensor emf for different levels of dissolved oxygen and for the saturation of sodium by $\mathrm{Na}_{2} \mathrm{O}$ (Noden equation) are also plotted in the figure. When the rate of the temperature variation was $1.5^{\circ} \mathrm{C} / \mathrm{min}$, as shown in Figure 10, the observed variation of the emf with temperature did not correspond to a constant oxygen concentration; the variation of temperature was too fast for the system to reach a stationary state. The optimum conditions are a slow rate of temperature variation $\left(0.1^{\circ} \mathrm{C} / \mathrm{min}\right)$ and a sufficient holding time. 


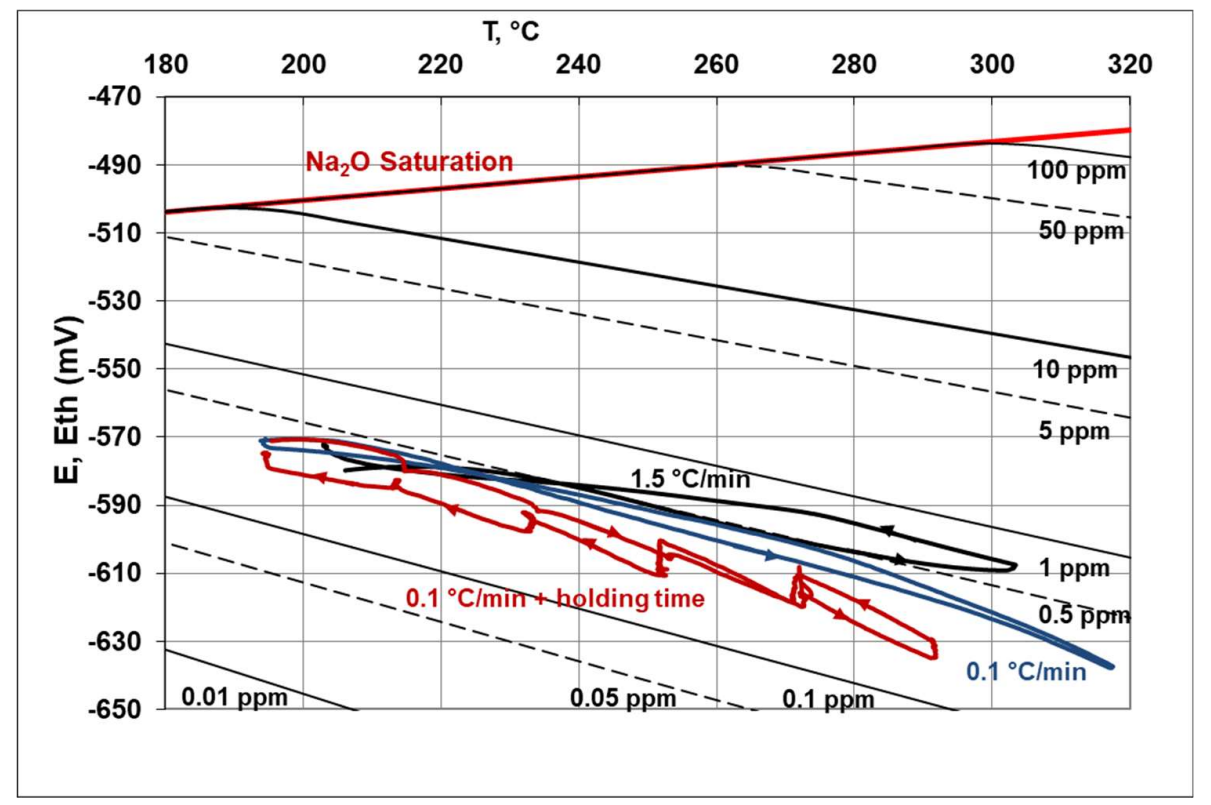

Figure 10: Variation of the emf of the H10Y sensor as a function of temperature for various rates of temperature variations. The theoretical variation of the emf for various oxygen concentration and the saturation straight line according to Noden equation are also plotted in the figure.

An example of the stabilization curve of the sensor emf after slow temperature variations $\left(0.1^{\circ} \mathrm{C} / \mathrm{min}\right)$ and eight hours of holding time in the temperature range of $200-300^{\circ} \mathrm{C}$ is illustrated in Figure 11.

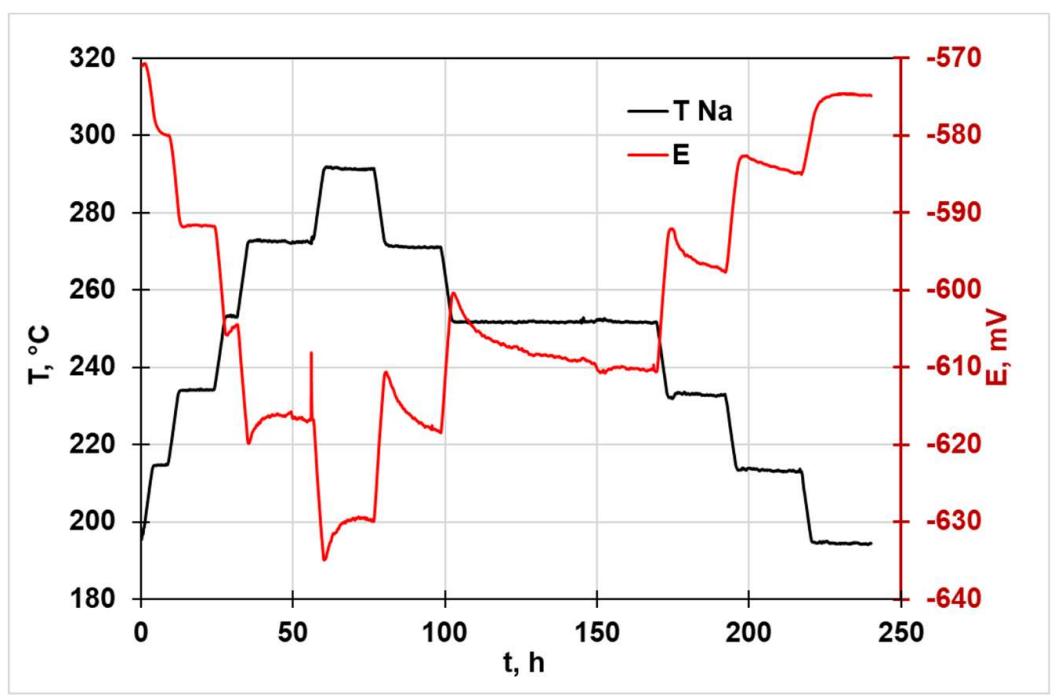

Figure 11: Stabilization of the sensor emf after slow variation of temperature $\left(0.1^{\circ} \mathrm{C} / \mathrm{min}\right)$ followed by at least eight hours of holding time, from $200^{\circ} \mathrm{C}$ to $300^{\circ} \mathrm{C}$, back and forth. 
Systematic overshoots were observed during the increase in temperature (up to $+5 \mathrm{mV}$ ) and during the decrease in temperature (up to $-9 \mathrm{mV}$ ); the higher the overshoot, the higher the temperature. The overshoot of response transients observed with various gas sensors at low temperatures resulted from a competition between two or more steps of the overall mechanism $[95,96]$. Moreover, the time required to obtain a stable emf was in the order of a few hours. It should be noted that the sensor response was fast after changing the oxygen concentration. The long time necessary to obtain a stable emf could be ascribed to the difficulty that the system had in reaching a stationary state at low temperatures. The measured concentration corresponded to a stationary state resulting from various redox systems, i.e., $\mathrm{Na} / \mathrm{Na}{ }_{2} \mathrm{O}, V_{O}^{\bullet \bullet} / V_{O}^{\bullet}$, and $\left[\mathrm{O}_{2}\right] /\left(\mathrm{Na}_{2} \mathrm{O}\right)_{\mathrm{Na}}$.

However, the final sensor output was remarkably steady; the emf deviation was less than 0.05 $\mathrm{mV}$ for one hour. The plot of $\mathrm{E}$ versus $\mathrm{T}$, taking into account the sensor emf obtained at the end of each holding time, is given in Figure 12. A linear variation of the measured emf $\mathrm{E}$ as a function of the temperature was observed, and the slope during the rise in temperature was practically equal to that observed during its decline, indicating that after sufficient holding time, a stationary state was observed, with a constant oxygen concentration. The use of zirconium foil as oxygen getter impeded the saturation of sodium in oxygen and allowed a very low oxygen concentration to be obtained. It should be noted that the getter activity of zirconium at temperatures below $300^{\circ} \mathrm{C}$ is poor, and it can be assumed that such activity does not noticeably change in the $200-300^{\circ} \mathrm{C}$ range, keeping the oxygen concentration in sodium constant within the experimental error. However, as shown in Figure 12, after a two-day hold at $293^{\circ} \mathrm{C}$, a very slight decrease in the oxygen concentration was observed, confirming the low activity of the zirconium getter. 


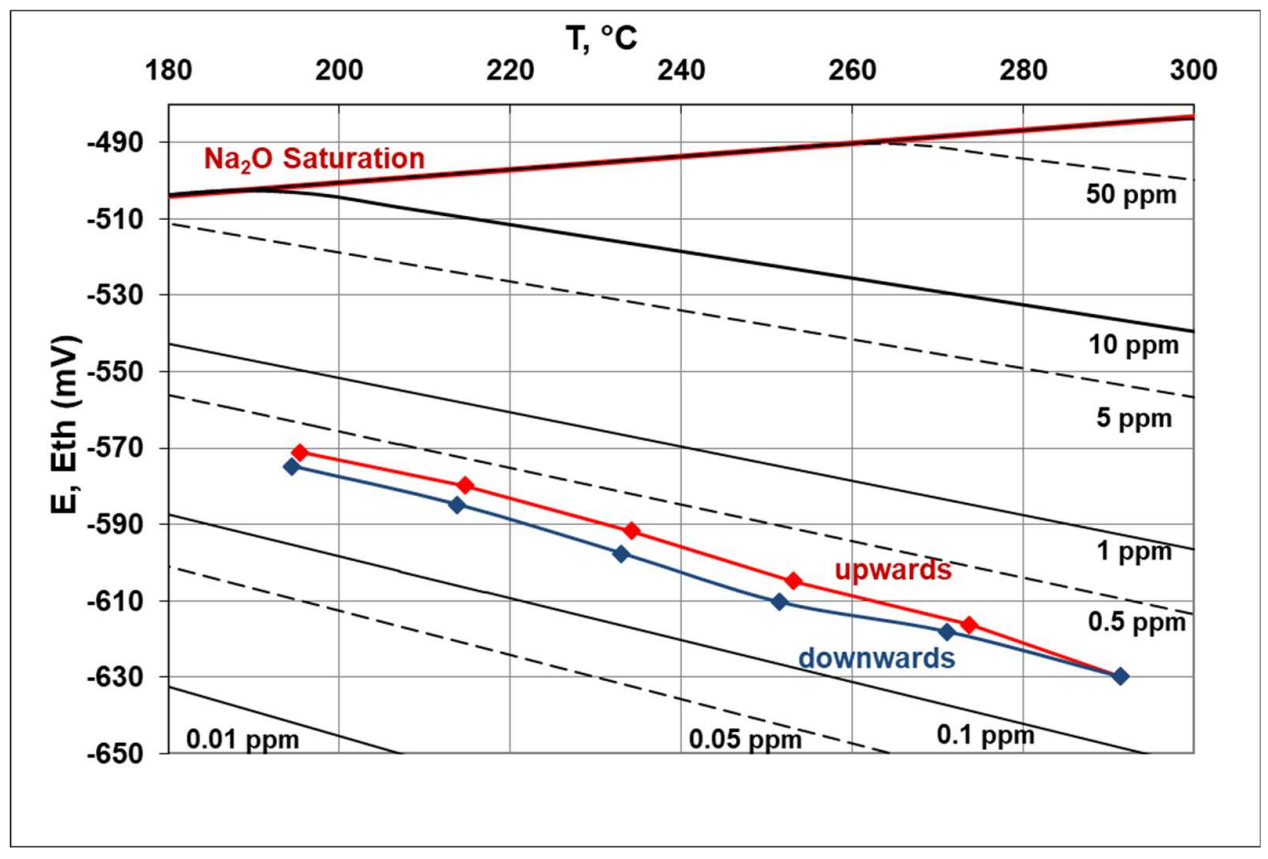

Figure 12: Measured emf of the $\mathrm{H} 10 \mathrm{Y}$ sensor vs. temperature at $340^{\circ} \mathrm{C}$.

According to equation 23 , the slope of the straight lines, $\mathrm{m}$, in $\mathrm{mV} / \mathrm{K}$, can be used for the calculation of the oxygen concentration:

$$
C_{\left(\left(N a_{2} O\right)\right)_{N a}}=\exp \left(\frac{0.051+m}{0.0431}\right)
$$

The offset can be estimated by extrapolation of the straight lines to $0 \mathrm{~K}$, giving $\mathrm{E}_{\text {intercept, }}$ and then, according to equation 23 ,

$$
E_{\text {offset }}=E_{\text {intersept }}-\mathrm{K}_{1}=\mathrm{E}_{\text {intersept }}+339.3
$$

The results of these calculations are provided in Table 2 .

Table 2: Estimation of the oxygen concentration and of the offset voltage at $200-300^{\circ} \mathrm{C}$.

\begin{tabular}{|c|c|c|c|c|}
\cline { 2 - 5 } \multicolumn{1}{c|}{} & Slope, $\mathrm{mV} / \mathrm{K}$ & $\mathrm{E}_{\text {intercept }}, \mathrm{mV}$ & $C_{\left(\left(\mathrm{Na}_{2} \mathrm{O}\right)\right)_{\mathrm{Na}}, \mathrm{ppm}}$ & $\mathrm{E}_{\text {offset, }} \mathrm{mV}$ \\
\hline Upwards & -0.616 & -280.7 & 0.021 & 58.5 \\
\hline Downwards & -0.626 & -281.1 & 0.016 & 58.2 \\
\hline
\end{tabular}

The slopes of the straight lines were obtained with very high accuracy, leading to a dissolved oxygen concentration in the order of $0.02 \mathrm{ppm} \pm 30 \%$ and an offset voltage, $\mathrm{E}_{\text {offset, }}$ of $58 \mathrm{mV} \pm$ $4 \%$. 
Figure 12 was replotted after the subtraction of $E_{\text {offset }}$ to the measured emf E (see Figure 13), with a comparison with the straight lines corresponding to $0.01,0.02$ and $0.04 \mathrm{ppm}$. In Figure 13 , linear regression by least square methods is presented together with the $90 \%$ confidence interval (dotted lines).

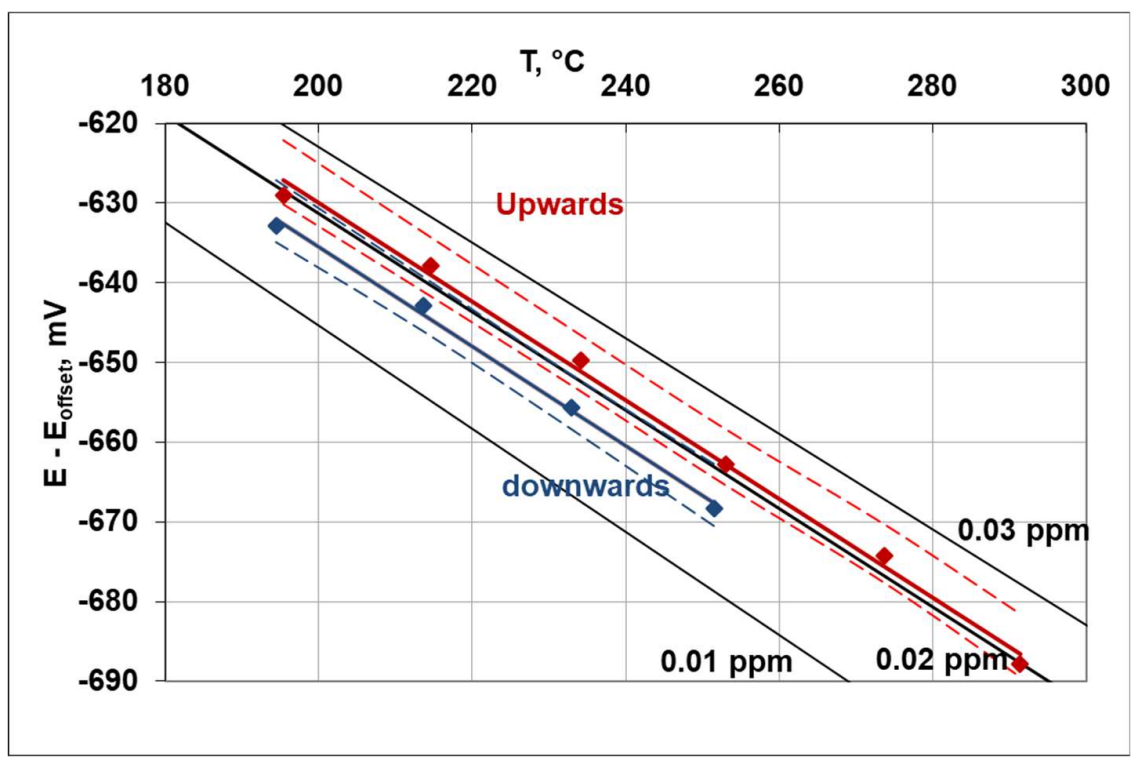

Figure 13: Variation of $\mathrm{E}-\mathrm{E}_{\text {offset }}$ with a temperature at $200-300^{\circ} \mathrm{C}$.

This plot confirms the stability of very low oxygen concentration $(0.02 \mathrm{ppm})$ during temperature cycling; the very small variation in the oxygen concentration was achieved within the $90 \%$ confidence interval. In previously published works [97], very low dissolved oxygen content of $0.001 \mathrm{ppm}$ has been observed over several months in a loop of liquid sodium. This very low and stable concentration has been ascribed to calcium impurities and metallic chromium resulting from the corrosion of stainless steel structures.

The lifetime of the sensor was ca. 1,350 hours for the three tested H10Y sensors. As has previously been determined $[11,14]$, the fracture of the tubes results from intergranular corrosion due to the presence of porosity and impurities in the grain boundaries. Even with high 
purity ceramic, the characterization of $\mathrm{H} 10 \mathrm{Y}$ after fracture revealed intergranular corrosion (see Figure $14 \mathrm{~b}$ ). It should be emphasized that the material has transgranular fracture before contact with sodium (Fig.14 a) and intergranular after tests under sodium (Fig.14 b).

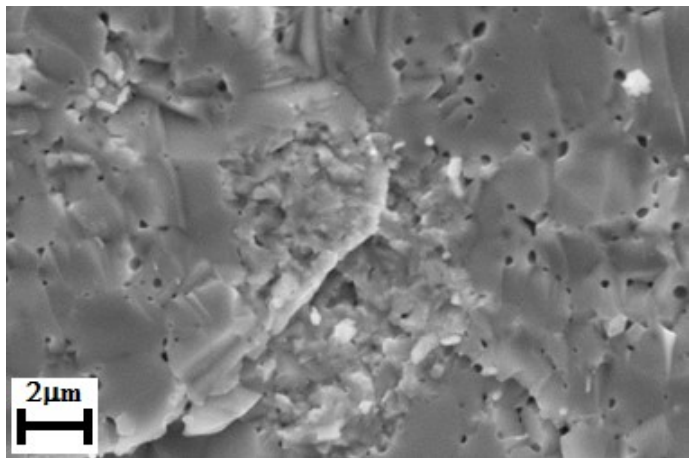

(a)

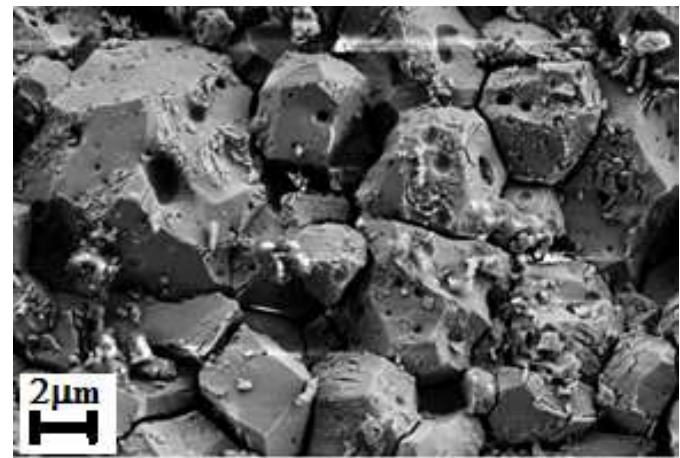

(b)

Figure 14: H10Y fracture facies of the tested tubes, (a) before electrochemical tests, (b) following sensor characterization tests under sodium $\left(1,350\right.$ hours, at $\left.200-300^{\circ} \mathrm{C}\right)$.

The H10Y sensor exhibited a very reproducible signal and remarkable stability under very low oxygen levels (ca. $0.02 \mathrm{ppm})$ and low temperatures $\left(200-300^{\circ} \mathrm{C}\right)$. It should be noted that the response time of the probe to a change in the oxygen concentration is quite short. However, at these temperatures, the system requires a few hours to achieve a steady state after a change in temperature. The results obtained with the hafnia-based electrolyte are promising in terms of lifetime when compared to electrolytes based on thoria or zirconia. Jayaraman et al. [7] have recently compared the lifetime of thoria- and zirconia-based sensors for measuring oxygen levels in sodium. The chemical resistance of the solid electrolyte depends widely, among other things, on the oxygen content, the temperature, the ceramic processing and the form of the ceramic used. However, the zirconia sensors failed after a few 10-hour tests, while in comparison YDT probes with an optimized design generally operated for a few thousand hours up to one year. The lifetime of the H10Y sensors that were tested in the form of a tube in the present study was ca. two months. 
In the following discussion, we compare the experimental results in the case of oxygen sensing in molten sodium for the three solid electrolytes (YDT, YSZ and H10Y) in terms of the offset voltage and slope of the Nernst law. The objective of this comparison is to propose hypotheses to explain the discrepancies between the results and expected values.

\section{Discussion}

An offset voltage is generally observed when comparing the experimental results from the theoretical calculation. It is necessary to differentiate between the absolute value of the offset voltage and the variability of the signals obtained with different sensors. The theoretical emf calculation required the Gibbs energy of the formation of $\operatorname{In}_{2} \mathrm{O}_{3}, \mathrm{Na}_{2} \mathrm{O}$ and the solubility relationship of oxygen in sodium. Various authors have analyzed the effect of the inaccuracies in the thermodynamic data on the sensor signal $[11,14,33,98-100]$. Offset voltages up to 100 $\mathrm{mV}$ have been observed with thoria-based electrolytes. We obtained an offset of ca. $30 \mathrm{mV}$ with YDT sensors, which corresponds with previously published values [11, 14]. With H10Ybased sensors, using the same thermodynamic data, we obtained an offset voltage of $58 \mathrm{mV}$, indicating a very small difference. This could be ascribed to a small electronic transport number (see the Wagner relationship in equation 17) or a small attack of the electrolyte by sodium, inducing a variation in the oxygen vacancy concentration at the interface (see sections 3.4 and 4.2.2). Such an interpretation cannot be made in the case of zirconia-based probes because the error was ca. $400 \mathrm{mV}$ [33]. It is admitted that the ionic transport number of stabilized zirconia in contact with sodium is noticeably less than 1 . Consequently, it is necessary to use the Wagner relationship:

$$
E=\frac{1}{2 F} \int_{\mu_{R}}^{\mu_{L}} t_{i o n} d \mu
$$

or the simplified equation (cf. equation 17): $\mathrm{E}=\bar{t}_{i} . \mathrm{E}_{\mathrm{th}}$ 
With stabilized zirconia, at $300^{\circ} \mathrm{C}$, for a theoretical value of $-1.85 \mathrm{~V} /$ Air and an experimental value in the order of $-1.4 \mathrm{~V} / \mathrm{Air}$, the corresponding mean ionic transport number will be ca. 0.75, which is in the order of the values found in the existing literature [33]. Moreover, it is known that such a low ion transport number will lead to an oxygen semipermeation flow that will have two consequences which depend on the "buffer capacity" on the sodium side: (i) a continuous increase in the activity of oxygen on the sodium side which does not seem to be observed, because the flow of matter is very low; and (ii) a polarization phenomenon, mainly on the sodium side involving an oxidation [48], which would tend to decrease the absolute value of the emf (which could indicate that the actual value of $\bar{t}_{i}$ is higher than that calculated using equation 14). Another explanation of the voltage offset could be related to the electrochemical reduction of stabilized zirconia by sodium (oxide vacancies $\left[V_{O}^{\bullet \bullet}\right]$ reduction leading to $V_{O}^{\bullet}$; see section 3.6). However, in these conditions, the measured emf would result in a mixed potential (see section 3.5) between the $V_{O}^{\bullet \bullet} / V_{o}^{\bullet}$ redox couple with a potential of ca. $-1.5 \mathrm{~V} /$ Air and the oxygen electrode reaction with a potential of ca. $-1.8 \mathrm{~V} /$ Air (for $1 \mathrm{ppm}$ of dissolved oxygen), corresponding to the global equation:

$$
(O)_{N a}+2 V_{o}^{\bullet}=O_{O}^{\times}+V_{O}^{\bullet \bullet}
$$

The mixed potential is between $-1.5 \mathrm{~V} /$ Air and $-1.8 \mathrm{~V} /$ Air, while the measured emf varies between -1.2 to $-1.4 \mathrm{~V} /$ Air. This feature does not indicate that there is no partial surface reduction of stabilized zirconia with the formation of $V_{O}^{*}$, but that the buffer capacity of the $V_{O}^{\bullet \bullet} / V_{O}^{\bullet}$ redox couple is insufficient to fix the potential. The oxygen semipermeability flux through the membrane will also slow down the migration of the reduced zone from the sodium interface toward the reference electrode. However, it has been shown that even if stabilized zirconia is only slightly reduced, the oxide surface is very reactive at low temperatures, i.e., electron concentration on the surface or subsurface of stabilized zirconia improves the kinetics of the electrode's reaction [101-103]. These features could explain the large deviation of the 
measured emf in comparison to the theoretical one and its stability at temperatures below $400^{\circ} \mathrm{C}$.

According to equation 8, the slope of the Nernst law depends on the temperature and on the number of electrons exchanged per mole of oxygen but also on the mean ionic transport number $\bar{t}_{i}$. In the case of a mixed ionic-electronic oxide, the Wagner relationship (17) induces a lowering of the observed Nernst slope. With thoria- or hafnia-based electrolytes, the slope of the Nernst law corresponds to an exchange of four electrons per mole of oxygen (see Figures 8 and 12). In previous research, with zirconia-based electrolyte in sodium, the same slope has been obtained at high temperatures, but at low temperatures, a noticeably higher slope has been observed [33]. Nollet et al. proposed hypotheses to account for this feature. These authors demonstrated that errors in the solubility curves used - such as Noden curves - cannot be responsible for the observed steep slope. They instead considered that the low operating temperature and the sodium attack of YSZ are responsible for the error in slope. However, their demonstration was based on an incorrect assertion, because they considered that the steeper than expected slope could be explained by a non-equilibrium mechanism involving oxygen transport across the electrolyte and by different mobilities of oxygen vacancies in the bulk and at the oxide surface, respectively. Moreover, these authors did not link these hypotheses with the Nernst equation. It should be recalled (see section 2) that establishing the Nernst equation requires that the surface thermodynamic is considered and that there is no transport through the cell. In our opinion, the observed slope of the Nernst equation cannot be a measurement error but must be explained by a new electrode reaction mechanism at low temperatures. As demonstrated in section 3.7, at low temperatures, the oxygen electrode reaction of a potentiometric gas sensor may involve two electrons or less per mole of oxygen, corresponding to equation 18. It has also been shown that dissolving peroxide ions in the solid electrolyte noticeably improves the cell emf stability [78-81]. As previously demonstrated, the theoretical 
slope of the Nernst law is then two times higher than that at high temperatures (see equation 22). As also previously noted (see section 3 ), the zirconia surface in contact with very reducing medium such as molten sodium is highly reactive. Moreover, it has been shown that peroxide ions are present in the molten sodium. Therefore, a model (schematized in Figure 15) can be proposed to take into account the high slope of the Nernst's law observed at low temperatures with stabilized zirconia as an electrolyte.

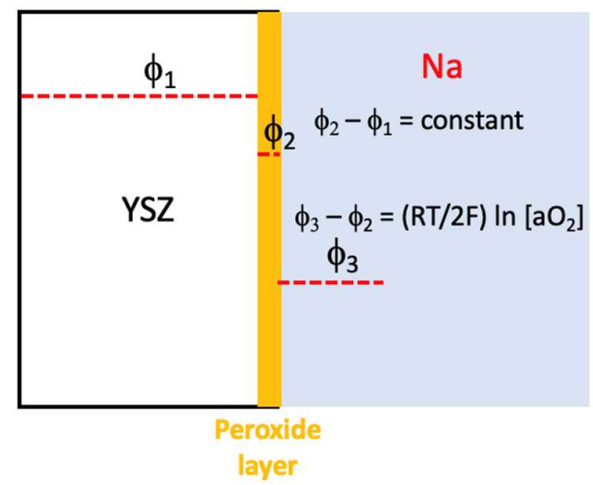

Figure 15: Hypothesis of oxygen electrode reaction on the sodium side involving peroxide ions (peroxide layer referred to as PL).

The hypothesis is that, at low temperature, the oxygen electrode reaction involved peroxide ions $O_{2}^{2-}$, according to

$$
\left(\mathrm{O}_{2}\right)_{\mathrm{Na}}+2 e^{\prime}=\mathrm{O}_{2}^{2-}
$$

leading to a slope twice the value observed at high temperature. However, it is necessary that the peroxide ion activity is constant and that there is a junction between the stabilized zirconia and the peroxide layer, as illustrated in Figure 15, with the following equilibrium:

$$
2 O_{Y S Z}^{2-}=O_{2, P L}^{2-}+2 e_{Y S Z}^{\prime},
$$

leading to an additional electrical potential variation $\Delta \phi=\phi_{2}-\phi_{1}$, which is constant, provided the activities of $\left(O_{Y S Z}^{2-}\right)$ and $\left(O_{2, P L}^{2-}\right)$ are constant. Moreover, equation 29 required an exchange of electrons that are present on the YSZ surface due to surface electrochemical reduction by molten sodium, leading to $V_{O}^{\bullet}$. 


\section{Conclusion}

Confirming previous studies in the temperature range of $1200-1600^{\circ} \mathrm{C}, \mathrm{HfO}_{2}$-based electrolytes can be considered as an alternative material for use in sensors that measure very low levels of oxygen in sodium at temperatures below $300^{\circ} \mathrm{C}$. Among the advantages of this electrolyte compared to other materials tested for this application are (i) a dramatic improvement of lifetime in comparison with stabilized zirconia and (ii) even if $\mathrm{HfO}_{2}$ is expensive, it is not a nuclear material, and air can be used as a reference of the probe. $\mathrm{HfO}_{2}$-based electrolytes have never been proposed for this application. Tests with long tubes of $\mathrm{HfO}_{2}-10 \mathrm{~mol} \% \mathrm{Y}_{2} \mathrm{O}_{3}$ were performed at a temperature below $300^{\circ} \mathrm{C}$, at a very low oxygen level $(0.01 \mathrm{ppm})$ with a very high signal stability and a lifetime of about $1,350 \mathrm{~h}$. Consequently, this electrolyte can be viewed as a promising material for sensing oxygen in molten sodium. To get closer to the performance of the YDT sensor, progress could be made by improving the sensor structure. Furthermore, the main sources of error in potentiometric sensors under extreme temperature and oxygen concentration conditions were reviewed. The offset voltage of the $\mathrm{HfO}_{2}$-based sensor is very close to that obtained with the YDT sensor. It is shown that the offset voltages obtained with the three main studied oxide electrolytes can be interpreted, taking into account both the deviation from unity of the ionic transport number of the electrolyte and the polarization phenomenon resulting at the interfaces. Moreover, for the zirconia-based sensor, an original interpretation of the steep slope of the Nernst equation obtained at low temperature (i.e., the sensor's response to the change in oxygen concentration) is proposed, based on the involvement of peroxide ions in the oxygen electrode equilibrium at the interface between zirconia electrolyte and molten sodium.

\section{Acknowledgments}


AREVA-CEZUS is acknowledged for providing $\mathrm{HfO}_{2}$ powder. Financial support for the characterization tests with stabilized zirconia electrolytes was provided by the GDR GEDEPEON (CEA - CNRS - EDF - AREVA NP). The authors are very grateful to the CEAGeneration 4/Structural material and technologies projects for another part of the financial support and to V. Lorentz, M. Rouhard, A. Muccioli, J. Unger, V. Ghetta and S. Tricoit for their participation and contribution in this long-term study. M. Tabarant is acknowledged for the fine and specific method of trace impurity analysis in ceramic materials by GD-MS.

\section{References}

[1] K. Kiukkola, C. Wagner, Galvanic Cells for the Determination of the Standard Molar Free Energy of Formation of Metal Halides, Oxides, and Sulfides at Elevated Temperatures, J. Electrochem. Soc. 104 (1957) 308-316. DOI: https://doi.org/10.1149/1.2428567.

[2] K. Kiukkola, C. Wagner, Measurements on Galvanic Cells Involving Solid Electrolytes, J. Electrochem. Soc. 104 (1957) 379-387. DOI: https://doi.org/10.1149/1.2428586.

[3] H. Peters, H.H. Mobius, Electrochemical investigation of the equilibria $\mathrm{CO}+1 / 2 \mathrm{O}_{2}=\mathrm{CO}_{2}$ and $\mathrm{C}+\mathrm{CO}_{2}=2$ CO, Z. Phys. Chem., Lpz. 209 (1958) 298-309.

[4] G.W. Horsley, A Possible Galvanic Cell Method for Monitoring the Activity of Oxygen in a Hot-trapped Sodium Coolant Circuit, AERE Report R-3037, Nov. 1959.

[5] I. Pakhomov, Research in the area of protection and intercircuit leak detection sodium/water SG, $17^{\text {th }}$ SFR CD \& BOP, PMB Meeting, Kaeri, 20-23 sept. 2014.

[6] H.U. Borgstedt, Influence of Liquid Sodium on Mechanical Properties of Steels, Refractory Alloys and Ceramics, in: Materials Issues for Generation IV Systems, Statut, Open Questions and Challenges, Nato, V. Ghetta, D. Gorse, D. Mazière and V. Pontikis (eds.), Springer, Dordrecht, 2008, pp. 461-480.

[7] V. Jayaraman, T. Gnanasekaran, Review - Evolution of the Development of In-Sodium Oxygen Sensor and Its Present Status, J. Electrochem. Soc. 163 (2016) B395-B402. DOI: https://doi.org/10.1149/2.1191607jes.

[8] H.S. Isaacs, Calibration of Electrochemical Oxygen Meters in Sodium Using Uranium, J. Electrochem. Soc. 119(4) (1972), 455-459. DOI: https://doi.org/10.1149/1.2404229.

[9] J. Jung, Über die Sauerstoffbestimmung in Flüssigen Natrium mit einer Elektrochemischen BetriebsmessSonde, J. Nuclear Mat. 56 (1975) 213-220. DOI: https://doi.org/10.1016/0022-3115(75)90091-4.

[10] M.R. Hobdell, C.A. Smith, Electrochemical techniques for measuring dissolved carbon, hydrogen and oxygen in liquid sodium, J. Nuclear Mat. 110 (1982) 125-139. DOI: https://doi.org/10.1016/0022-3115(82)90137-4.

[11] R.G. Taylor, R. Thompson, Testing and performance of electrolytic oxygen meters for use in liquid sodium, J. Nuclear Mat. 115 (1983) 25-38. DOI: https://doi.org/10.1016/0022-3115(83)90339-2.

[12] D. Jakeš, J. Kral, J. Burda, M. Fresl, Development of Electrochemical oxygen meter for liquid sodium, Solid State Ionics 13 (1984) 165-173. DOI: https://doi.org/10.1016/0167-2738(84)90052-3.

[13] D. Jakeš, J. Šebková, L. Kubicek, Compatibility problems of indium and tin reference electrodes in an oxygen meter for liquid sodium, J. Nuclear Mat. 132 (1985) 88-91. DOI: https://doi.org/10.1016/00223115(85)90399-X.

[14] R.G. Taylor, R. Thompson, Harwell MkIII electrochemical oxygen sensor - testing and performance in liquid sodium, Harwell, Avril 1987, p. 22.

[15] R. Sridharan, D. Krishnamurthy, C.K. Mathews, Thermodynamic properties of ternary oxides of alkali metals from oxygen potential measurements, J. Nuclear Mat. 167 (1989) 265-270. DOI: https://doi.org/10.1016/0022$\underline{3115(89) 90450-9 .}$. 
[16] H. Ullmann, K. Teske, Determination of Oxygen Activities in Melts and Solid Materials by Solid Electrolyte Cell, Sensors and Actuators B 4 (1991) 417-423. DOI: https://doi.org/10.1016/0925-4005(91)80145-A.

[17] K. Künstler, H.-J. Lang, H. Heyne, V.D. Ananiev, E.B. Kirplkov, Ju.V. Kulpin, Monitoring and control of impurities in the primary circuit of the IBR-2 reactor, J. Nuclear Mat. 200(2) (1993) 169-176. DOI: https://doi.org/10.1016/0022-3115(93)90327-U.

[18] R. Ganesan, V. Jayaraman, S. Rajan Babu, R. Sridharan, T. Gnanasekaran, Development of Sensors for Online Monitoring of Nonmetallic Impurities in liquid sodium, J. Nuclear Sci. Techn. 48 (2011) 483-489. DOI: https://doi.org/10.1080/18811248.2011.9711723 .

[19] R. Ganesan, S. Vivekanandhan, T. Gnanasekaran, G. Periaswami, R.S. Srinivasa, Novel approach for the bulk synthesis of nanocrystalline yttria doped thoria powders via polymeric precursor routes, J. Nuclear Mat. 325 (2004) 134-140. DOI: https://doi.org/10.1016/j.jnucmat.2003.11.003.

[20] V. Jayaraman, D. Krishnamurthy, R. Ganesan, A. Thiruvengadasami, R. Sudha, M.V.R. Prasad, T. Gnanasekaran, Development of yttria-doped thoria solid electrolyte for use in liquid sodium systems, Ionics 13 (2007) 299-303. DOI: https//doi.org/10.1007/s11581-007-0113-z.

[21] M. Gabard, Y. Cherkaski, N. Clavier, L. Brissonneau, M.C. Steil, J. Fouletier, A. Mesbah, N. Dacheux, Preparation, characterization and sintering of yttrium-doped $\mathrm{ThO}_{2}$ for oxygen sensors applications, Journal of Alloys and Compounds 689 (2016) 374-382. DOI: https//doi.org/ 10.1016/j.jallcom.2016.07.271.

[22] I.C. Cosentino, R. Muccillo, Powder synthesis and sintering of high density thoria-yttria ceramics, J. Nucl. Mat. 304 (2002) 129-133. DOI: https://doi.org/10.1016/S0022-3115(02)00884-X.

[23] J.B. Goodenough, Ceramic Solid Electrolytes, Solid State Ionics 94 (1997) 17-25. DOI: https://doi.org/10.1016/S0167-2738(96)00501-2.

[24] V.V. Kharton, F.M.B. Marques, J.A. Kilner, A. Atkinson., in: Solid State Electrochemistry I: Fundamentals, Materials and their Applications, V.V. Kharton Ed., Wiley, 2009, pp. 301-334.

[25] J. Sunarso, S. Baumann, J.M. Serra, W.A. Meulenberg, S. Liu, Y.S. Lin, J.C. Diniz da Costa, Mixed ionicelectronic conducting (MIEC) ceramic-based membranes for oxygen separation, J. Membr. Sci. 320 (2008) 1341. DOI: https://doi.org/10.1016/j.memsci.2008.03.074.

[26] K. Zhang, J. Sunarso, Z. Shao, W. Zhou, C. Sun, S. Wang, S. Li, Research progress and materials selection guidelines on mixed conducting perovskite-type ceramic membranes for oxygen production, RSC Adv. 1 (2011) 1661-1676. DOI: https//doi.org/10.1039/C1RA00419K.

[27] H.J.M. Bouwmeester, A.J. Burggraaf, Dense Ceramic Membranes, in: P.J. Gellings, H.J.M. Bouwmeester (eds), The CRC handbook of solid state electrochemistry, CRC Press, Boka Raton, 1996, pp. 481-553.

[28] Electrochemistry of Glasses and Glass Melts, Including Glass Electrodes, H. Bach, F.G.K. Baucke, D. Krause, (eds.), Springer-Verlag, Berlin, 2001.

[29] T. Tran, M.P. Brungs, Application of oxygen electrodes in glass melts. 2. Oxygen probes for the measurement of oxygen potential in sodium disilicate glass, Phys. Chem. Glasses 21 (1980) 178-183.

[30] C.M.S. Rodrigues, J.A. Labrincha, F.M.B. Marques, Degradation of Zirconia Based Oxygen Sensors in Glass Melting Furnaces, Ionics 2 (1996) 12-18. DOI: https//doi.org/10.1007/BF02375862.

[31] C.M.S. Rodrigues, J.A. Labrincha, F.M.B. Marques, Postmortem characterization of one yttria stabilized zirconia (YSZ)-based oxygen sensor, Solid State Ionics 136-137 (2000) 671-675. DOI: https://doi.org/10.1016/S0167-2738(00)00336-2.

[32] J. Fouletier, M.C. Steil, J.L. Courouau, F. Balbaud-Celerier, V. Lorentz, T. Dufrenoy, V. Ghetta, Mise au point de systèmes de mesures électrochimiques des traces d'oxygène en milieu sodium, Gedepeon Workshop, Paris 2011.

[33] B.K. Nollet, M.G. Hvasta, M.H. Anderson, D. Morgan, J.A. Schneider, Development of an Electrochemical Oxygen Sensor for Liquid Sodium Using a Yttria Stabilized Zirconia Electrolyte, J. Electrochem. Soc. 164 (2017) B10-B22. DOI: https://doi.org/10.1149/2.0021702jes.

[34] S.H. Shin, J.J. Kim, J.A. Jeong, K.J. Choi, S.I. Choi, J.H. Kim, Development of Electrochemical Oxygen Sensor for High Temperature Sodium Environment Application, Trans. Korean Nuclear Soc. Spring Meet., Jeju, Korea, 17-18 May 2012. 
[35] S.H. Shin, J.H. Lee, J.K. Lee, J. Lim, S. Choi, G. Kim, J.H. Kim, Measurement of Emf in Liquid Sodium Using a Gadolinia-Doped Ceria Solid Electrolyte, J. Electrochemical Soc. 162 (2015) B152-B158. DOI: https://doi.org/10.1149/2.0301507jes.

[36] N.M. Tallan, W.C. Tripp, R.W. West, Electrical Properties and Defect Structure of $\mathrm{HfO}_{2}$, J. Am. Ceram. Soc. 50 (1967) 279-283. DOI: https://doi.org/10.1111/j.1151-2916.1967.tb15109.x.

[37] J.D. Schieltz, J.W. Patterson, D.R. Wilder, Electrolytic behaviour of yttria-stabilised hafnia, J. Electrochem. Soc. 118 (1971) 1257-1261. DOI: https//doi/org/10.1149/1.2408301.

[38] V. Šály, M. Hartmanová, V.B. Glushková, Electrical behaviour of $\mathrm{HfO}_{2}$ stabilized with rare earths, Solid State Ionics 36 (1989) 189-192. DOI: https://doi.org/10.1016/0167-2738(89)90168-9.

[39] S.S. Pandit, A. Weyl, D. Janke, High-temperature ionic and electronic conduction in zirconate and hafnate compounds, Solid State Ionics 69 (1994) 93-99. DOI: https://doi.org/10.1016/0167-2738(94)90396-4.

[40] A. Weyl, D. Janke, High-temperature ionic conduction in multicomponent solid oxide solutions based on $\mathrm{HfO}_{2}$, J. Am. Ceram. Soc. 79 (1996) 2145-2155.DOI: https://doi.org/10.1111/j.1151-2916.1996.tb08949.x.

[41] S. Zhuiykov, An investigation of conductivity, microstructure and stability of $\mathrm{HfO}_{2}-\mathrm{ZrO}_{2}-\mathrm{Y}_{2} \mathrm{O}_{3}-\mathrm{Al}_{2} \mathrm{O}_{3}$ electrolyte compositions for high-temperature oxygen measurement, J. Europ. Ceram. Soc. 20 (2000) 967-976. DOI: https//doi.org/10.1016/S0955-2219(99)00233-2.

[42] J. Fouletier, E. Siebert, Potentiometric solid-state oxygen sensors, Ion-Selective Electrode Rev. 8 (1986) 133151.

[43] H. Näfe, How to check the validity of Nernst's law in a potentiometric solid electrolyte galvanic cell, Solid State Ionics 113-115 (1998) 205-217. DOI: https://doi.org/10.1016/S0167-2738(98)00374-9.

[44] C.O. Park, S.A. Akbar, W. Weppner, Ceramic electrolytes and electrochemical sensors, J. Mat. Sci. 38 (2003) 4639-4660. DOI: https://doi.org/10.1023/A:1027454414224.

[45] H.D. Wiemhöfer, W. Göpel, Fundamentals and Principles of Potentiometric Gas Sensors Based upon Solid Electrolytes, Sensors Actuators B 4 (1991) 365-372. DOI: https://doi.org/10.1016/0925-4005(91)80137-9.

[46] W.C. Maskell, B.C.H. Steele, Solid State potentiometric oxygen gas sensor, J. Appl. Electrochem. 16 (1986) 475-489. DOI: https://doi.org/10.1007/BF01006843.

[47] H.U. Borgstedt, C.K. Mathews, Applied Chemistry of the Liquid Alkali Metals, Plenum Press, New-YorkLondon, 1987.

[48] M.C. Steil, J. Fouletier, P.-M. Geffroy, Surface exchange polarization vs. gas concentration polarization in permeation through mixed ionic-electronic membrane, J. Membr. Sci. 541 (2017) 457-464. DOI: https://doi.org/10.1016/j.memsci.2017.07.028.

[49] J. Fouletier, H. Seinera, M. Kleitz, Measurement and Regulation of Oxygen-Content in Selected Gases Using Solid Electrolyte Cells, 2. Differential Gauge, J. Appl. Electrochem., 5 (1975) 177-185. DOI: https://doi.org/10.1007/BF00613213.

[50] C.-S. Chen, Z.-P. Zhang, G.-S. Jiang, C.-G. Fan, W. Liu, Oxygen permeation through $\mathrm{La}_{0.4} \mathrm{Sr}_{0.6} \mathrm{Co}_{0.2} \mathrm{Fe}_{0.8} \mathrm{O}_{3-\delta}$ membrane, Chem. Mat. 13 (2001) 2797-2800. DOI: https://doi.org//10.1021/cm000809a.

[51] S.B. Adler, X.Y. Chen, J.R. Wilson, Mechanisms and rate laws for oxygen exchange on mixed-conducting oxide surfaces, J. Catal. 245 (2007) 91-109. DOI: https://doi.org/10.1016/j.jcat.2006.09.019.

[52] M.Z. Bazant, Theory of chemical kinetics and charge transfer based on nonequilibrium thermodynamics, Acc. Chem. Res. 46 (2013) 1144-1160. DOI: https://doi.org/10.1021/ar300145c.

[53] P.-M. Geffroy, L. Guironnet, H.J.M. Bouwmeester, T. Chartier, J.-C. Grenier, J.-M. Bassat, Influence of oxygen partial pressure on the oxygen diffusion and surface exchange coefficients in mixed conductors, J. Europ. Ceram. Soc. 39 (2019) 59-65. DOI: https://doi.org/10.1016/j.jeurceramsoc.2018.03.034.

[54] A.J. Bard, L.R. Faulkner, Electrochemical Methods: Fundamental and Applications, Wiley, New York (USA), 1980.

[55] J. Fouletier, P. Fabry, M. Kleitz, Electrochemical Semipermeability and the Electrode Microsystem in Solid Oxide Electrolyte Cells, J. Electrochem. Soc. 123 (1976) 204-213. DOI: https://doi.org/10.1149/1.2132787.

[56] J. Fouletier, E. Mantel, M. Kleitz, Performance characteristics of conventional oxygen gauges, Solid State Ionics 6 (1982) 1-13, https://doi.org/10.1016/0167-2738(82)90089-3. 
[57] J.W. Patterson, The Physics of Electronic Ceramics, L.L. Hench, D.B. Dove, (eds.), Marcel Dekker Inc., New York, 1971, chap. 5.

[58] J.W. Patterson, Conduction Domains for Solid Electrolytes, J. Electrochem. Soc. 118 (1971) 1033-1039. DOI: https://doi.org/10.1149/1.2408241.

[59] H.L. Tuller, A.S. Nowick, Doped Ceria as a Solid Oxide Electrolyte, J. Electrochem. Soc. 122 (1975) 255259. DOI: https://doi.org/10.1149/1.2134190.

[60] E.C. Subbarao, H.S. Maiti, Solid Electrolytes with Oxygen Ion Conduction, Solid State Ionics 11 (1984) $317-$ 338. DOI: https://doi.org/10.1016/0167-2738(84)90024-9.

[61] J. Fouletier, V. Ghetta, Potentiometric Sensors for High Temperature Liquids, in: Materials Issues for Generation IV Systems, Status, Open Questions and Challenges, V. Ghetta, D. Gorse, D. Mazière, V. Pontikis, eds., Springer, Dordrecht, The Netherlands, 2008, pp. 445-459.

[62] T.H. Etsell, S.N. Flengas, The electrical properties of solid oxide electrolytes, Chem. Rev. 70 (1970) 339 376. DOI: https://doi.org/10.1021/cr60265a003.

[63] M. Kleitz, E. Siebert, J. Fouletier, Recent Developments on Oxygen Sensing with Solid Electrolyte Cells, Proc. Int. Meeting Chem. Sensors, T. Seiyama, K. Fueki, J. Shiokawa, S. Suzuki (eds.), Elsevier, 1983, pp. $262-$ 272.

[64] N. Fukatsu, I. Osawa, Z. Kozuka, Oxygen potential control in $\mathrm{CO}_{2}-\mathrm{CO}-\mathrm{O}_{2}$ mixtures circulating in a closed system by coulometric titration, Trans. JIM 19 (1978) 25-34.

[65] J. Fouletier, Gas Analysis with Potentiometric Sensors. A Review, Sensors Actuators 3 (1982/83) $295-314$. DOI: https://doi.org/10.1016/0250-6874(82)80030-9.

[66] W.L. Worrell, J.L. Iskoe, in: Fast Ion Transport in Solids, Solid Batteries and Devices, W. van Gool, (Ed.), North-Holland Publ. Comp., Amsterdam, 1973, pp. 513-521.

[67] V.M. Shelemet'ev, Effect of the design of the reference electrode on the metrological characteristics of the solid electrolyte oxygen sensor, in: $5^{\text {th }}$ Conference "Heavy Liquid Metal Coolants in Nuclear Technologies" (HLMC-2018), SSC RF - IPPE, Obninsk, Russia, 8-10 Oct. 2018.

[68] P. Fabry, E. Siebert, Electrochemical Sensors, in: The CRC Handbook of Solid State Chemistry, P.J. Gellings, H.J.M. Bouwmeester, eds., CRC Press, London, pp. 329-369.

[69] H. Lux, "Säuren” und "Basen” im Schmelzfluss: Die Bestimmung der Sauerstoffionen-Konzentration, Z. Elektrochem. Angew. 45 (1939) 303-309.

[70] H. Flood, T. Forland, The Acidic and Basic Properties of Oxides, Acta Chemica Scandinavica 1(6) (1947) 592-604. DOI: https://doi.org/10.3891/acta.chem.scand.01-0592.

[71] A. Martin, J.C. Poignet, J. Fouletier, M. Allibert, D. Lambertin, G. Bourgès, Yttria-stabilized zirconia as membrane material for electrolytic deoxidation of $\mathrm{CaO}-\mathrm{CaCl}_{2}$ melts, J. Appl. Electrochem. 40 (2010) $533-542$. DOI: https://doi.org/10.1007/s10800-009-0025-X.

[72] C.O. Park, J.W. Fergus, N. Miura, Jinsu Park, Angi Choi, Solid-state electrochemical gas sensors, Ionics 15 (2009) 261-284. DOI: https://doi.org /10.1007/s11581-008-0300-6.

[73] P. Fabry, M. Kleitz, C. Déportes, Sur I'Utilisation d'une Electrode Ponctuelle dans les Cellules à Oxyde Electrolyte Solide, II. Application à la Détermination des Tensions d'Oxydoréduction des Défauts Ponctuels dans l'Electrolyte, J. Solid State Chem. 5 (1972) 230-239 (in French). DOI : https://doi.org/10.1016/00224596(73)90186-2.

[74] S. Boulfrad, E. Djurado, J. Fouletier, Electrochemical characterization of nanostructured zirconias, Solid State Ionics 180 (2009) 978-983. DOI: https://doi.org/10.1016/j.ssi.2009.04.014.

[75] P. Fabry, Etude électrochimique des défauts ponctuels dissous dans les électrolytes solides - Application aux oxydes fluoritiques, State Thesis, Grenoble, 1976 (in French).

[76] J. Janek, C. Korte, Electrochemical blackening of yttria-stabilized zirconia - morphological instability of the moving reaction front, Solid State Ionics 116 (1999) 181-195. DOI: https://doi.org/10.1016/S01672738(98)00415-9.

[77] M. Kleitz, E. Siebert, P. Fabry, J. Fouletier, Solid-State Electrochemical Sensors, in: Sensors - A Comprehensive Survey, W. Göpel, J. Hesse, J.N. Zemel (Eds), Chemical and Biochemical Sensors, Part I, Vol. 2 , 1992, VCH, Weinheim, pp. 341-428. 
[78] E. Siebert, J. Fouletier, S. Vilminot, Characteristics of an Oxygen Gauge at temperature lower than $200^{\circ} \mathrm{C}$, Solid State Ionics 9 \& 10 (1983) 1291-1294. DOI: https://doi.org/10.1016/0167-2738(83)90166-2.

[79] E. Siebert, J. Fouletier, M. Kleitz, Oxygen Sensing with Solid Electrolyte Cells from Room Temperature up to $250^{\circ} \mathrm{C}$, J. Electrochem. Soc. 134 (1987) 1573-1578. DOI: https://doi.org/10.1149/1.2100712.

[80] E. Siebert, J. Fouletier, M. Bonnat, Mechanism of the Oxygen Sensing Electrode on Solid Halide Electrolytes, Solid State Ionics 28-30 (1988) 1693-1696. DOI: https://doi.org/10.1016/0167-2738(88)90444-4.

[81] M. Kleitz, T. Iharada, F. Abraham, G. Mairesse, J. Fouletier, Electrode materials for zirconia sensors working at temperatures lower than $500 \mathrm{~K}$, Sensors and Actuators B 13 (1993) 27-30. DOI: https://doi.org/10.1016/09254005(93)85314-Z.

[82] R.G. Taylor, R. Thompson, UKAEA Report, AERE R- 10365 (1982).

[83] C. Schroer, J. Konys, A. Verdaguer, J. Abellà, A. Gessi, A. Kobzova, S. Babayan , J.-L. Courouau, Design and testing of electrochemical oxygen sensors for service in liquid lead alloys, J. Nucl. Mat. 415 (2011) 338-347. DOI: https://doi.org/10.1016/j.jnucmat.2011.04.045.

[84] J.L. Courouau, Electrochemical oxygen sensors for on-line monitoring in lead-bismuth alloys: status of development, J. Nucl. Mat. 335 (2004) 254-259. DOI: https://doi.org10.1016/j.jnucmat.2004.07.020.

[85] J.L. Courouau, Chemistry control and monitoring systems, in: NEA/OECD (Ed.), Handbook on LeadBismuth Eutectic Alloy and Lead Properties, Materials Compatibility, Thermal-Hydraulics and Technologies, Chapter 4, Edition 2015, Report N07268, pp. 185-238.

[86] T. Iharada, A. Hammouche, J. Fouletier, M. Kleitz, J.C. Boivin, G. Mairesse, Electrochemical characterization of BIMEVOX oxide-ion conductors, Solid State Ionics 48 (1991) 257-265. DOI: https://doi.org/10.1016/01672738(91)90040-I.

[87] M. Guillodo, J. Fouletier, L. Dessemond, P. Del Gallo, Redox stability of BIMEVOX.10 materials $(\mathrm{ME}=\mathrm{Co}, \mathrm{Cu})$, Electrochim. Acta 47 (2002) 2809-2815. DOI: https://doi.org10.1016/S0013-4686(02)00167-6.

[88] C. Salles, M.-C. Steil, J. Fouletier, M. Duttine, A. Wattiaux, D. Marinha, Long-term stability of iron-doped calcium titanate $\mathrm{CaTi}_{0.9} \mathrm{Fe}_{0.1} \mathrm{O}_{3-\delta}$ under non-reactive and reactive gases, J. Membr. Sci. 583 (2019) 171-179. DOI: https://doi.org/10.1016/j.memsci.2019.04.049.

[89] M. Rivollier, J.-L. Courouau, M. Tabarant, C. Blanc, M.-L. Giorgi, Oxidation of 316L(N) stainless steel in liquid sodium at $650^{\circ} \mathrm{C}$. J. Nucl. Mat. 500 (2018) 337-348. DOI: https://doi.org/10.1016/j.jnucmat.2017.12.037.

[90] B. Barkia, J.L. Courouau, E. Perrin, V. Lorentz, M. Rivollier, R. Robin, L. Nicolas, C. Cabet, T. Auger, Investigation of crack propagation resistance of $304 \mathrm{~L}, 316 \mathrm{~L}$ and $316 \mathrm{~L}(\mathrm{~N})$ austenitic steels in liquid sodium, J. Nucl. Mat. 507 (2018) 15-23. DOI: https://doi.org/10.1016/j.jnucmat.2018.04.036.

[91] M. Rivollier, Corrosion des aciers austénitiques par le sodium liquide en présence d'oxygène, PhD Thesis, CentraleSupélec, 2017 (in French).

[92] I. Barin, Thermochemical Data of Pure Substances, Third Edition, 1995, VCH, Weinheim.

[93] J. D. Noden, A general equation for the solubility of oxygen in liquid sodium, J. Br. Nucl. Energy Soc. 12 (1973) 57-62.

[94] R. Thompson, G.R. Taylor, R.C. Asher, C.C.H. Wheatley, R. Dawson, Experience of the production, performance and application of Harwell oxygen meter tubes, in: $2^{\text {nd }}$ Int. Conf. on Liquid Metal Technol. in Energy Production Proceed., J.M. Dahlke (ed.), American Nuclear Society, Washington, DC, 1980, pp. 16.9-16.14.

[95] N. Matsunaga, G. Sakai, K. Shimanoe, N. Yamazoe, Diffusion equation-based study of thin film semiconductor gas sensor-response transient, Sensors and Actuators B, 83 (2002) 216-221. DOI: https://doi.org/ 10.1016/S0925-4005(01)01043-7.

[96] S. Suresh, K.M. B. Urs, A.T. Vasudevan, S. Sriram, V.B. Kamble, Analysis of Unusual and Instantaneous Overshoot of Response Transients in Gas Sensors, Phys. Status Solidi RRL 2019, 1800683. DOI: https://doi.org/10.1002/pssr.201800683.

[97] J.M. McKee, F.A. Smith, E.R. Koehl, Evaluation of hydrogen and oxygen meters in sodium as steam generator leak detectors, in: $2^{\text {nd }}$ Int. Conf. on Liquid Metal Technol. in Energy Production Proceed., J.M. Dahlke (ed.), American Nuclear Society, Washington, DC, 1980, pp. 15:29-15:36.

[98] D.L. Smith. Monitoring and Measurement of Oxygen Concentrations in Liquid Sodium. International Conference on Liquid Metal Technology in Energy Production, Champion, PA, May 3-6, 1976. 
[99] B. Minushkin and M. Kolodney. Development of a Continuous Electrochemical Meter for Oxygen in Sodium. Final Report, United Nuclear Corporation Project 2191, December 15, 1967, UNC-5131.

[100] H. Ullman, T. Reetz, W. Richter at al., Experience in Application of Electrochemical Cells for the Determination of Oxygen Activity in Sodium, , in: $2^{\text {nd }}$ Int. Conf. on Liquid Metal Technol. in Energy Production Proceed., J.M. Dahlke (ed.), American Nuclear Society, Washington, DC, 1980, pp. 16:1-16:8.

[101] D. Chatain, F. Chabert, V. Ghetta, J. Fouletier, New Experimental Setup for Wettability Characterization under Monitored Oxygen Activity: I, Role of Oxidation State and Defect Concentration on Oxide Wettability by Gold, J. Am. Ceram. Soc. 76 (1993) 1568-1576.DOI: https://doi.org/10.1111/j.1151-2916.1993.tb03941.x.

[102] E.J.L. Schouler,M. Kleitz, E. Forest, E. Fernandez, P. Fabry, Overpotential of $\mathrm{H}_{2}-\mathrm{H}_{2} \mathrm{O}, \mathrm{Ni} / \mathrm{YSZ}$ electrodes in steam electrolyzers, Solid State Ionics 5 (1981) 559-562. DOI: https://doi.org/10.1016/0167-2738(81)90316-7.

[103] M. Kleitz, E. Siebert, J. Fouletier, Recent Developments in Oxygen Sensing with a Solid Electrolyte Cell, in: Proc. Int. Meet. Chem. Sensors, T. Seiyama Ed., Kodansha, Elsevier, Amsterdam, 1983, pp. 262-272. 